Check for updates

Cite this: RSC Adv., 2017, 7, 53278

Received 26th October 2017

Accepted 13th November 2017

DOI: $10.1039 / c 7 r a 11827 a$

rsc.li/rsc-advances

\section{Environmentally benign and diastereoselective synthesis of 2,4,5-trisubstituted-2-imidazolines $\dagger$}

\author{
Hai Anh Le Phuong, (D) $t^{\mathrm{a}}$ Levente Cseri, (D) $t^{\mathrm{a}}$ George F. S. Whitehead, (D) ${ }^{\mathrm{b}}$ \\ Arthur Garforth, (D) a Peter Budd (D) ${ }^{\text {b }}$ and Gyorgy Szekely (D) *a
}

2-Imidazolines are heterocycles with a wide range of applications in biomedical science, pharmaceuticals, surfactants and catalysis. The 2,4,5-trisubstituted derivatives are conventionally prepared through the reaction of aromatic aldehydes and ammonia, requiring harsh conditions and toxic solvents. Herein, we report a sustainable, one-pot synthetic route to obtain cis or trans diastereomers of 2,4,5-trisubstituted2 -imidazolines. The reaction parameters, such as the ammonia source, the substituents of the aromatic aldehydes and the effect of temperature and solvent, were systematically explored. The synthesis was attempted in sixteen different green solvents. Reaction kinetics and quantum mechanical studies (DFT B3LYP/6-31G(d,p)) revealed the elementary steps of the cyclisation and refuted two common speculations. The limitations of the synthesis were explored through varying the $p_{-}, \mathrm{O}_{-}$, and $\mathrm{m}$ substituents on the aldehyde as well as employing heterocyclic and non-aromatic derivatives. Ten out of the twelve products synthesised in this work can be solely purified by crystallisation, without the need for extraction or chromatography. Owing to the bulky nature of the products, the applicability of membrane-based purification was demonstrated to further improve the sustainability of the synthesis.

\section{Introduction}

2-Imidazoline derivatives are an important class of heterocycles with a wide range of industrial applications (Fig. 1). They exhibit biological activity and can be found in natural products such as topsentines or spongotines, which have been attractive for biomedical purposes due to their antitumor, antiviral and antiinflammatory characteristics. ${ }^{1}$ Several pharmaceutical compounds that contain a 2 -imidazoline ring have been synthesised and studied for blood pressure control, hyperglycemia, depression and schizophrenia. ${ }^{2}$ Imidazolines and imidazolinium ions have been used as surfactants,${ }^{3}$ ionic liquids, ${ }^{4}$ ionic polymers, ${ }^{5}$ and in the field of coordination chemistry and catalysis. ${ }^{6-10}$ Among the 2-imidazoline derivatives, 2,4,5-triaryl imidazolines (also called amarines) have been gaining increased interest because their hydrolysis provides 1,2-diaryl-

${ }^{a}$ School of Chemical Engineering \& Analytical Science, The University of Manchester, The Mill, Sackville Street, Manchester, M1 3BB, UK. E-mail: gyorgy.szekely@ manchester.ac.uk; Tel: +44 (0)161 3064366

${ }^{b}$ School of Chemistry, The University of Manchester, Oxford Road, Manchester, M13 9PL, UK

$\dagger$ Electronic supplementary information (ESI) available: Synthetic procedures; ${ }^{1} \mathrm{H}$ NMR, ${ }^{13} \mathrm{C}$ NMR, MS, HRMS, FTIR spectra; HPLC methods, chromatograms, kinetic calculations; DFT computational methods \& raw data; single crystal XRD data, membrane separation. CCDC 1576088-1576090, 1582071. For ESI and crystallographic data in CIF or other electronic format see DOI: $10.1039 / \mathrm{c} 7 \mathrm{ra} 11827 \mathrm{a}$

$\ddagger$ These authors equally contributed to this work. 1,2-diaminoethanes featuring a $C_{2}$-symmetric structure, important in catalysis. ${ }^{11-13}$

The reported syntheses for obtaining 2,4,5-trisubstituted-2imidazolines are summarised in Table 1. 2,4,5-Trisubstituted2-imidazolines were successfully synthesised from benzylamine and carbon tetrachloride, ${ }^{14}$ and 1,2-cyclic sulphates and amidine. ${ }^{15}$ However, none of these syntheses were as prominent as the reaction from benzaldehyde and ammonia. ${ }^{16}$ Benzaldehyde reacts with liquid ammonia to produce hydrobenzamide (also known as 1,3,5-triaryl-2,4-diazapentadiene), an intermediate which upon heating or employing strong base

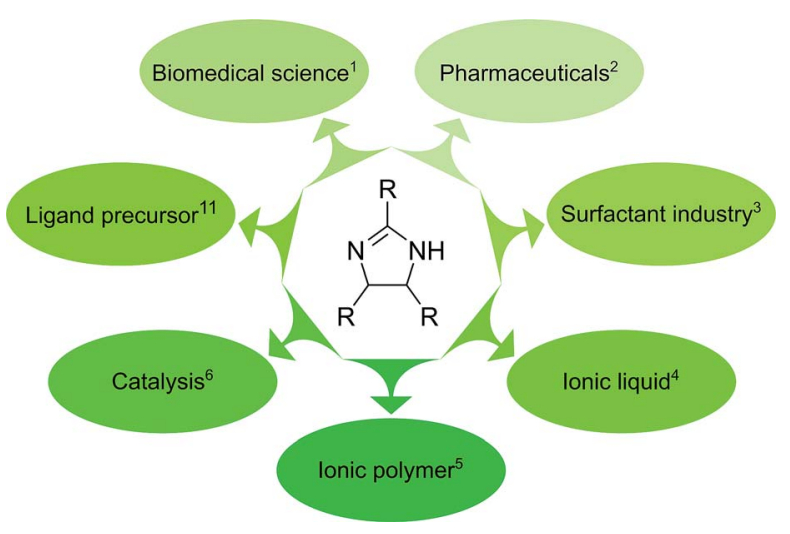

Fig. 1 2-Imidazoline derivatives are versatile building blocks for various applications. 
Table 1 Comparison of the synthetic procedures for 2,4,5-trisubstituted-2-imidazolines

\begin{tabular}{|c|c|c|c|c|c|c|}
\hline Reactants & $T\left({ }^{\circ} \mathrm{C}\right)$ & Solvent & Additives & Purification & Yield (\%) & Ref. \\
\hline Benzylamine \& carbon tetrachloride & 125 & Carbon tetrachloride & $\mathrm{Cu}, \mathrm{Fe}$ catalyst & Column chromatography & $1-24$ & 14 \\
\hline 1,2-Cyclic sulphates \& amidine & $\begin{array}{l}85-162 \\
\text { (reflux) }\end{array}$ & $\begin{array}{l}\text { Dimethoxyethane/Methoxyethyl } \\
\text { ether }\end{array}$ & - & Extraction & $22-64$ & 15 \\
\hline 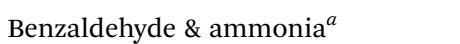 & 130 & Benzene & - & Recrystallisation & 81 & 12 \\
\hline Benzaldehyde \& HDMS & 120 & - & - & Column chromatography & $47-89$ & 19 \\
\hline Benzaldehyde \& urea & 120 & DMF & $\mathrm{Cs}_{2} \mathrm{CO}_{3}$ & Column chromatography & $40-79$ & 20 \\
\hline
\end{tabular}

${ }^{a}$ Two-step reaction. The 2,4-diazapentadiene intermediate was isolated via recrystallisation from cyclohexane. The 2-imidazoline product was purified by recrystallisation from petroleum ether.

deprotonates and subsequently forms amarine, supposedly via disrotatory pericyclic closure. ${ }^{\mathbf{1 1}, \mathbf{1 7}}$ The rate of pericyclisation usually depends on both the steric and electronic character of the substituents. ${ }^{18}$ However, the effect of substituents on the synthesis of 2-imidazolines and the reaction mechanism have yet to be investigated.

Notwithstanding the moderate to good yields, most reactions require additives, extensive purification, or harsh conditions, i.e., high temperature, toxic or banned solvents. In addition, additives and catalysts were usually used for the preparation of the desired product, which results in additional waste that has to be managed. While attempts have been made towards a more sustainable synthesis of 2,4,5-trisubstituted-2imidazolines, there is a need for exploring green solvents and purification processes.

The 21st century's sustainability grand challenge requires the chemical industry to employ mild reaction conditions, and non-toxic, non-flammable chemicals and solvents, with the aim of minimising environmental impact. ${ }^{21}$ Solvents for reaction and purification account for more than $80 \%$ of the total mass used for the production of pharmaceuticals, ${ }^{22}$ and consume $60 \%$ of the total energy. ${ }^{23}$ The solvent selection guides established by pharmaceutical companies provide practical advice to reduce the environmental burden associated with solvent usage. ${ }^{\mathbf{2 4 , 2 5}}$ Following the guidelines, sixteen different green solvents were screened for the syntheses presented in this work. As an effective process intensification tool due to the mild conditions and low energy consumption, ${ }^{26}$ membrane technology is a sustainable alternative to conventional purification techniques such as crystallisation and chromatography, ${ }^{27}$ which can be more easily implemented in continuous processing. ${ }^{28}$ Consequently, the potential of membrane-based purification of the 2-imidazoline products was evaluated.

Herein, we report the development toward an environmentally benign, diastereoselective, one-pot synthesis of 2,4,5trisubstituted-2-imidazolines employing non-toxic ammonium salts, green solvents and purification. The kinetics and reaction mechanism were explored to reveal the governing factors of the pericyclisation. To the best of our knowledge the kinetic studies and quantum mechanical calculations for the reaction of aldehyde and ammonia to produce 2,4,5-trisubstituted-2imidazolines have not yet been reported.

\section{Results and discussion}

The reaction optimisation was initiated by investigating the effect of temperature and solvent on the reaction of 4 -(trifluoromethyl)benzaldehyde and $\left(\mathrm{NH}_{4}\right)_{2} \mathrm{CO}_{3}$ (Table 2). In line with the 12 principles of green chemistry, ${ }^{21}$ all reactions were performed at mild temperatures $\left(20-50{ }^{\circ} \mathrm{C}\right)$ in solvents, which were chosen according to GlaxoSmithKline's solvent selection guide. ${ }^{25}$ Although, the isolated yield markedly increased with the temperature up to $40{ }^{\circ} \mathrm{C}$ (entries 1-3), a considerable decrease at $50{ }^{\circ} \mathrm{C}$ was observed (entry 4 ), which indicates the

Table 2 The effect of temperature and solvent on the reaction ${ }^{a}$

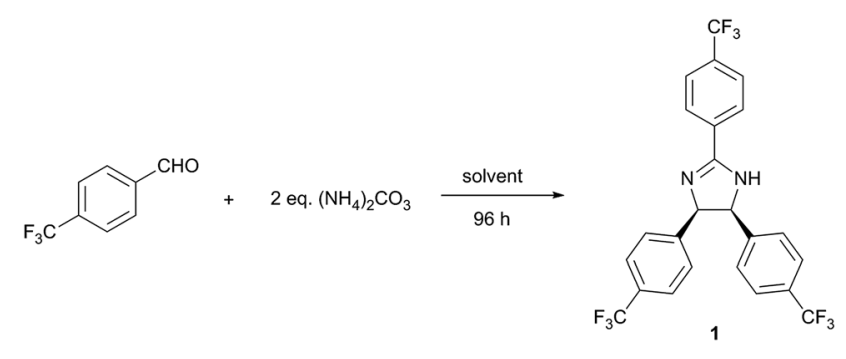

\begin{tabular}{llll}
\hline Entry & Solvent & $T\left({ }^{\circ} \mathrm{C}\right)$ & Yield $^{b}(\%)$ \\
\hline 1 & 2 -MeTHF & 20 & 21 \\
2 & 2 -MeTHF & 30 & 40 \\
3 & 2-MeTHF & 40 & 67 \\
4 & 2-MeTHF & 50 & 48 \\
5 & Ethyl lactate & 40 & 66 \\
6 & Propylene carbonate & 40 & 66 \\
7 & Sulfolane & 40 & 65 \\
8 & 2-Propanol & 40 & 55 \\
9 & Methanol & 40 & 41 \\
10 & DMSO & 40 & 38 \\
11 & MTBE & 40 & 22 \\
12 & CPME & 40 & 11 \\
13 & 1-Butanol & 40 & 10 \\
14 & Butyl acetate & 40 & 6 \\
15 & Dimethyl carbonate & 40 & 2 \\
16 & Water & 40 & 1
\end{tabular}

${ }^{a}$ The reactions were carried out with 4-(trifluoromethyl)benzaldehyde $(3 \mathrm{mmol}),\left(\mathrm{NH}_{4}\right)_{2} \mathrm{CO}_{3}(6 \mathrm{mmol})$, and solvent $(6 \mathrm{~mL})$ for $96 \mathrm{~h} .{ }^{b}$ Isolated yield. ${ }^{c}$ The reaction was performed for $24 \mathrm{~h}$ at which point product formation stopped according to HPLC monitoring. 
decomposition of $\left(\mathrm{NH}_{4}\right)_{2} \mathrm{CO}_{3}$. The influence of solvent is presented in entries 3 and 5-16 in Table 2. While 1 was obtained in most of the solvents, good yield was only obtained in polar solvents (2-MeTHF, ethyl lactate, propylene carbonate, sulfolane, 2-propanol, methanol and DMSO), probably due to the stabilisation of the ionic intermediates. High solvent polarity favours the reaction, which resulted in reduced reaction time. For instance, the use of DMSO resulted in virtually $100 \%$ conversion of the starting material within $24 \mathrm{~h}$, while achieving the same conversion in 2-MeTHF required $96 \mathrm{~h}$. However, the higher reaction rate facilitated by-product formation, which subsequently decreased selectivity and isolated yield of $\mathbf{1}$. The product was not formed in Cyrene, choline chloride : urea (1:2 $\mathrm{n} / \mathrm{n}$ ) deep eutectic solvent (DES) and [bmim][OAc] ionic liquid. Cyrene, a relatively new green alternative for polar aprotic solvents, ${ }^{29}$ resulted in quasi-complete substrate consumption within $24 \mathrm{~h}$. Nonetheless, a multicomponent reaction mixture was obtained without any trace of $\mathbf{1}$, which reiterates the labile and reactive nature of this new solvent. ${ }^{30}$ Considering the tradeoff between selectivity and reaction rate, 2-MeTHF, ethyl lactate, propylene carbonate and sulfolane provide a suitable solvent for the reaction as they produced 1 with high selectivity in a manageable reaction time. However, since the product isolation from the last three is more solvent and energy intensive (extraction and evaporation), 2-MeTHF was used for further reaction optimisation.

To study the effect of ammonia sources ( 2 eq.) on the reaction, non-toxic ammonium salts of acids covering a wide range of $\mathrm{p} K_{\mathrm{a}}$ values $(-6.30$ to 10.32 ) were selected (Table 3$)$. The highest conversion was achieved using $\left(\mathrm{NH}_{4}\right)_{2} \mathrm{CO}_{3}$ (entry 1), while moderate and poor yield was obtained with $\mathrm{NH}_{4} \mathrm{HCO}_{3}$ and $\mathrm{NH}_{4} \mathrm{OAc}$ (entries 2 and 3), respectively. $\mathrm{NH}_{4} \mathrm{HCOO}$ (entry 4 ) did

Table 3 The effect of ammonia source on the reaction ${ }^{a}$

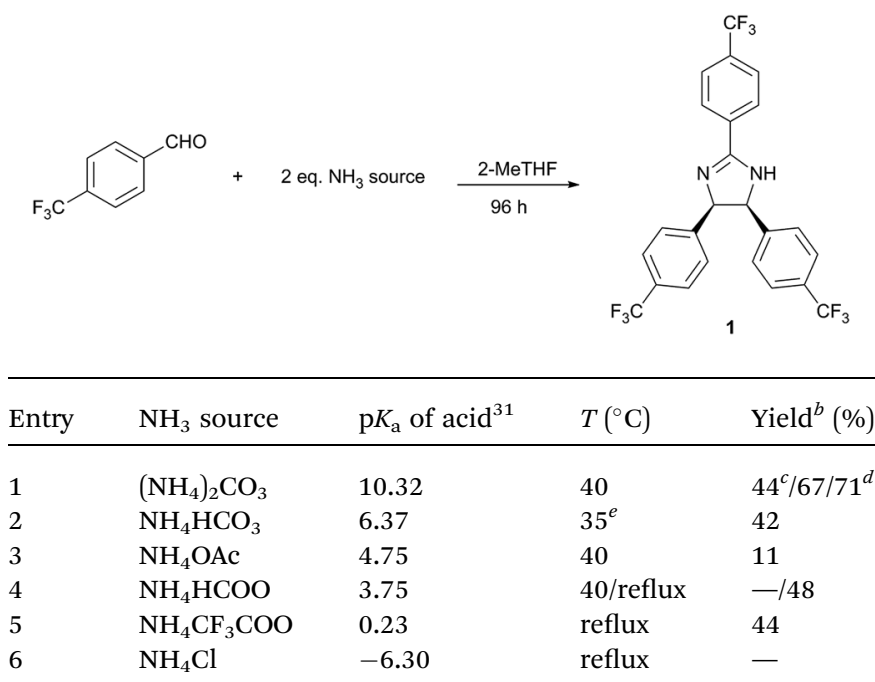

${ }^{a}$ The reactions were carried out with 4-(trifluoromethyl)benzaldehyde ( $3 \mathrm{mmol})$, ammonium salt $(6 \mathrm{mmol})$, and 2-MeTHF $(6 \mathrm{~mL})$ for $96 \mathrm{~h}$. ${ }^{b}$ Isolated yield. ${ }^{c} 1$ eq. ammonium salt $(3 \mathrm{mmol})$ was used. ${ }^{d} 4$ eq. ammonium salt $(12 \mathrm{mmol})$ was used. ${ }^{e}$ Instead of $40{ }^{\circ} \mathrm{C}$ the reaction was performed at $35{ }^{\circ} \mathrm{C}$ due to the decomposition of $\mathrm{NH}_{4} \mathrm{HCO}_{3}$ at $40{ }^{\circ} \mathrm{C} .{ }^{32}$ not provide the desired product at $40{ }^{\circ} \mathrm{C}$, but a moderate yield was obtained at the reflux temperature of $81{ }^{\circ} \mathrm{C}$. Moderate yield was also achieved using $\mathrm{NH}_{4} \mathrm{CF}_{3} \mathrm{COO}$ at reflux (entry 5). In contrast, no product was formed with $\mathrm{NH}_{4} \mathrm{Cl}$ (entry 6) under reflux conditions. These results suggest that employing the ammonium salt of a weaker acid (therefore with higher $\mathrm{p} K_{\mathrm{a}}$ value) leads to increased reaction rate due to the more favoured dissociation of the salt and the more basic environment. In addition, the amount of ammonia source was also investigated (entry 1). The increase of ammonium carbonate from 1 to $2 \mathrm{eq}$. led to $23 \%$ yield enhancement. However, further increase to 4 eq. did not result in significant improvement.

The effect of both electron withdrawing and electron donating $p$-substituents on the reaction were systematically investigated (Table 4). Substrates with strongly or moderately electron-withdrawing groups (EWG) (entries 1-7), i.e., moderate to high Hammett sigma constants $(\sigma=0.45-0.82)$, provided the desired product in good to excellent yield. The substrate with weakly electron-withdrawing bromide group (entry $8 ; \sigma=0.23$ ) only afforded the 2 -imidazoline derivative in poor yield. Reactions with non-EWGs $(-\mathrm{H},-\mathrm{OH})$ were attempted but did not yield the imidazoline products.

In order to further explore the effect of EWGs on the reaction rate, the kinetics of the reaction was studied. The reactions of $\left(\mathrm{NH}_{4}\right)_{2} \mathrm{CO}_{3}$ with 4-nitrobenzaldehyde, 4-(pentafluorosulfanyl)benzaldehyde, 4-(trifluoromethyl)benzaldehyde, and methyl 4formyl benzoate were chosen as model systems because they

Table 4 The effect of $p$-substituents on the reaction ${ }^{a}$

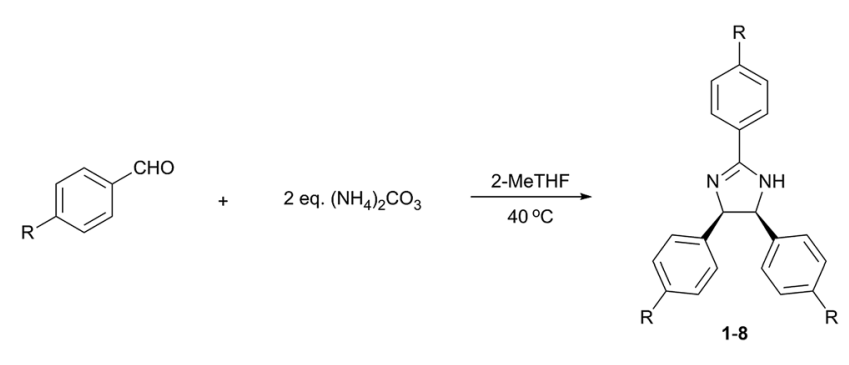

\begin{tabular}{llllll}
\hline Entry & $\mathrm{R}$ & $\sigma^{b}(-)$ & $t(\mathrm{~h})$ & Yield $^{c}(\%)$ & Product \\
\hline 1 & $-\mathrm{NMe}_{3}{ }^{+} \mathrm{I}^{-d}$ & 0.82 & 24 & 83 & $\mathbf{2}$ \\
2 & $-\mathrm{NO}_{2}{ }^{-}$ & 0.78 & 24 & $58 / 85$ & $\mathbf{3}$ \\
3 & $-\mathrm{SO}_{2} \mathrm{Me}^{d}$ & 0.72 & 48 & 69 & $\mathbf{4}$ \\
4 & $-\mathrm{SF}_{5}$ & 0.68 & 36 & 87 & $\mathbf{5}$ \\
5 & $-\mathrm{CN}^{-}$ & 0.66 & 96 & 68 & $\mathbf{6}$ \\
6 & $-\mathrm{CF}_{3}$ & 0.54 & 96 & 67 & $\mathbf{1}$ \\
7 & $-\mathrm{COOMe}$ & 0.45 & 96 & 65 & 7 \\
8 & $-\mathrm{Br}$ & 0.23 & 168 & 8 & $\mathbf{8}$ \\
9 & $-\mathrm{H}$ & 0.00 & 168 & - & -
\end{tabular}

${ }^{a}$ Unless otherwise noted, the reaction was performed with $p$-substituted benzaldehyde ( $3 \mathrm{mmol}),\left(\mathrm{NH}_{4}\right)_{2} \mathrm{CO}_{3}(6 \mathrm{mmol})$, and 2-MeTHF $(6 \mathrm{~mL})$ at $40{ }^{\circ} \mathrm{C} .{ }^{b}$ Hammett sigma constant. ${ }^{33}{ }^{c}$ Isolated yield. ${ }^{d}$ Due to the poor substrate solubility in pure 2-MeTHF, the reaction required the use of 2-MeTHF $(5 \mathrm{~mL})$ and DMSO $(1 \mathrm{~mL})$ solvent mixture. ${ }^{e}$ The lower $58 \%$ isolated yield is a result of excessive by-product formation when $\left(\mathrm{NH}_{4}\right)_{2} \mathrm{CO}_{3}(6 \mathrm{mmol})$ was used, while the higher $85 \%$ isolated yield was obtained with the use of $\mathrm{NH}_{4} \mathrm{OAc}(6 \mathrm{mmol})$ ammonia source. This result implies that $\mathbf{3}$ is sensitive to oxidation under basic conditions. 
provided the desired product under the same conditions with a considerable yield, and they cover a wide range of $\sigma$ (0.450.78). A consecutive reaction, $3 \mathrm{~A} \rightarrow \mathrm{B} \rightarrow \mathrm{C}$, was suggested for the reaction kinetics based on the formation of stable intermediate $\mathrm{B}$ identified as hydrobenzamide in the literature. ${ }^{11}$ In order to obtain the reaction rate constants $k_{1}$ and $k_{2}$, the rate eqn (1)-(3) have to be solved.

$$
\begin{gathered}
\frac{\mathrm{d}[\mathrm{A}]}{\mathrm{d} t}=-3[\mathrm{~A}]^{n} k_{1} \\
\frac{\mathrm{d}[\mathrm{B}]}{\mathrm{d} t}=[\mathrm{A}]^{n} k_{1}-[\mathrm{B}] k_{2} \\
\frac{\mathrm{d}[\mathrm{C}]}{\mathrm{d} t}=[\mathrm{B}] k_{2}
\end{gathered}
$$

where $[\mathrm{A}],[\mathrm{B}]$ and $[\mathrm{C}]$ are the concentrations of component of the aldehyde, hydrobenzamide, and product, respectively; and $n$ stands for the rate order of the first reaction. The $\mathrm{B} \rightarrow \mathrm{C}$ reaction is considered as first order because the transformation from the hydrobenzamide to product is an intramolecular ring closure. However, the order of the $\mathrm{A} \rightarrow \mathrm{B}$ reaction is not that evident because it is composed of several elementary steps including, the formation of aldehyde-ammonia adducts and water elimination. The rate order of the reaction was chosen based on the following method: the value of $n$ was varied from 1 to 5 and then the obtained differential equations were fitted to the experimental data with the least square method. The goodness of fitting was evaluated with the sum of squared deviations (SSD) and a rate order was selected where the SSD (summarised in Table S1, ESI $\dagger$ ) was at the minimum. The lowest SSD was obtained at $n=3$ in three out of four sets of experimental data. Consequently, a third order model was chosen as the overall rate order for the first chemical transformation. As shown on the plots in Fig. 2, the conversion profiles in most cases $\left(-\mathrm{NO}_{2},-\mathrm{CF}_{3}\right.$, -COOMe) are sigmoidal: the product formation is slow in the first period, however, it increases in the second period, then it

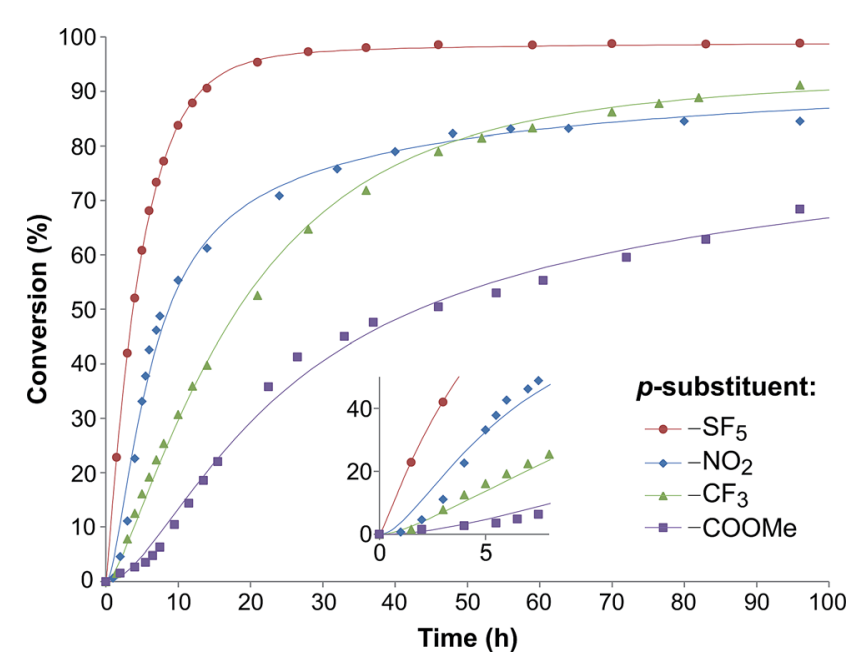

Fig. 2 Substrate conversion profile as a function of reaction time. Symbols denote the experimental data, while the lines signify the calculated plots. decreases again. Finally, a plateau is reached when no further product is formed. The sigmoidal plots indicate the formation and accumulation of hydrobenzamide intermediate, which reveals that the $\mathrm{A} \rightarrow \mathrm{B}$ reaction is faster than the $\mathrm{B} \rightarrow \mathrm{C}$ reaction. Due to the rapid reaction rate for the first step of the $-\mathrm{SF}_{5}$ derivative synthesis the sigmoidal shape is not prominent.

In order to investigate the relationship between the reaction rates and the electron-withdrawing substituents, the calculated $k_{1}$ and $k_{2}$ values are displayed as a function of the $\sigma$ in Fig. 3a. Although increasing rate constants for both $k_{1}$ and $k_{2}$ were expected with increasing $\sigma$ no direct relationship between the three constants was found. The rate of hydrobenzamide formation increases from $\sigma=0.45$ (-COOMe) until $\sigma=0.68\left(-\mathrm{SF}_{5}\right)$, however, $k_{1}$ significantly drops at $\sigma=0.78$. The rate constant of the intramolecular ring closure decreases between $\sigma=0.45$ (-COOMe) and $\sigma=0.54\left(-\mathrm{CF}_{3}\right)$ and then grows with increasing electronwithdrawing property. These results could be the consequence of other factors, such as low solubility of the intermediate.

Density functional theory computational analysis (DFT B3LYP/6-31G(d,p)) revealed the cyclisation mechanism of 1 from the hydrobenzamide intermediate (1hb) (Fig. 4). The deprotonation of $\mathbf{1 h b}$ forms a high energy carbanion intermediate (1cU), which stabilises by the translation of the
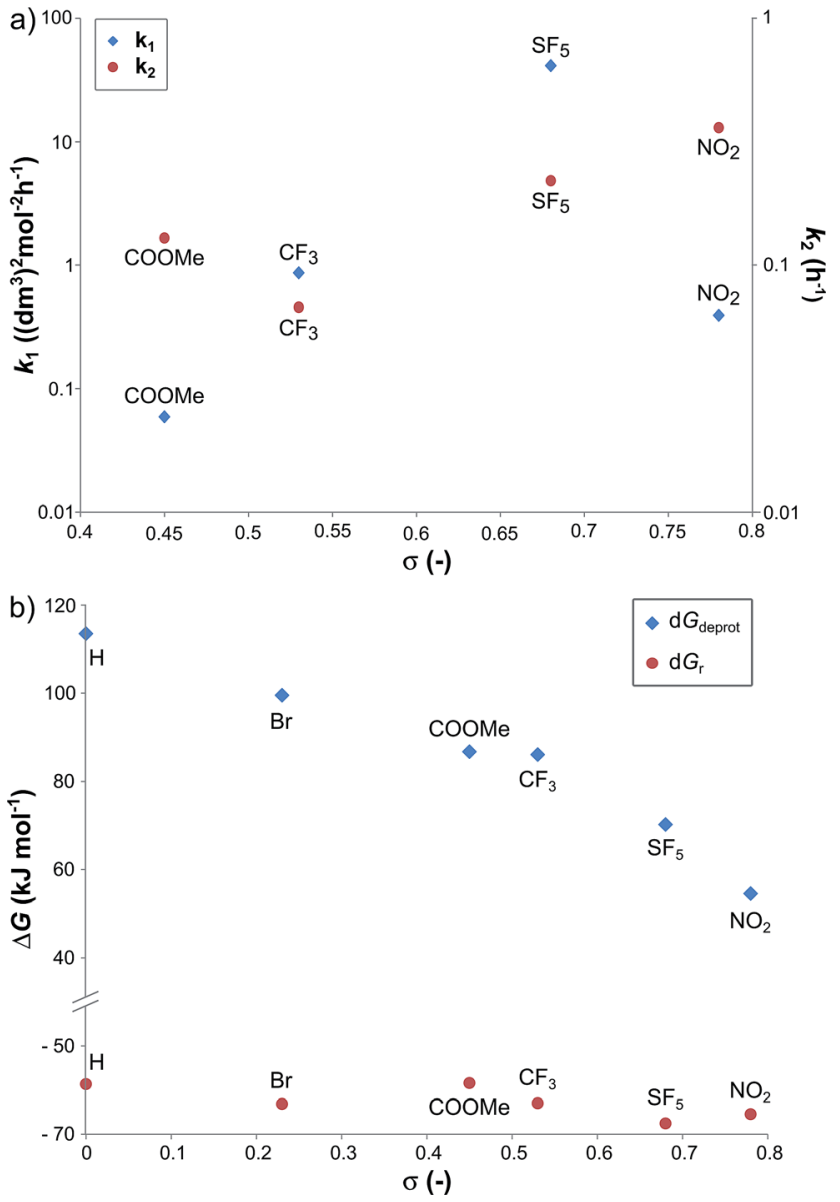

Fig. 3 The $k_{1}$ and $k_{2}$ reaction rate constants (a), and the relative Gibbs free energy of the $\mathrm{B} \rightarrow \mathrm{C}$ reaction $\left(\Delta G_{\mathrm{r}}\right)$ and the deprotonation step $\left(\Delta G_{\text {deprot }}\right)($ b) as a function of Hammett sigma constant $(\sigma)$. 
ammonium counter ion. Subsequent protonation of $\mathbf{1 c U}$ on its nitrogen atom results in $\mathbf{1 z w}$ zwitterionic intermediate, which provides 1 via ring closure. The Gibbs free energy of both the cyclisation $\left(\Delta G_{\mathrm{r}}\right)$ and the deprotonation $\left(\Delta G_{\text {deprot }}\right)$ was derived for substituents with different electron-withdrawing properties (different $\sigma$ values). The dependence of $\Delta G_{\mathrm{r}}$ on $\sigma$ is negligible; however, the $\Delta G_{\text {deprot }}$ values significantly decrease with higher $\sigma$ values (Fig. 3b). Consequently, the reaction favours EWGs, which is in line with the experimental observations (see Table 4).

The DFT results refuted two speculations about the mechanism of the cyclisation. First, the cyclisation from the carbanion species with electron-withdrawing substituents is not favourable thermodynamically (Table S2, ESI $\dagger$ ), despite speculations that the reaction proceeds with the ring closure of the carbanion intermediate leading to the negatively charged imidazoline which is the deprotonated form of 2-imidazoline (Scheme S1a, ESI $\dagger) .{ }^{11}$ Second, $\mathbf{1 c U}$ is the energetically most favoured carbanion conformer (Table 5). Despite speculations that $\mathbf{1 c W}$ has the lowest energy due to the lack of steric hindrance between $\mathrm{H}(4)$ and $\mathrm{H}(5)^{16}$ 1cU has a quasi-planar structure, which allows the conjugation of the $\pi$ system to be extended to the whole molecule. However, the steric repulsion between the $\mathrm{H}(5)$ and $\mathrm{H}(34)$ atoms in $\mathbf{1 c S}$ and $\mathbf{1 c W}$ forces the ring to turn out of the plane, which decreases the conjugation. The cyclisation was further studied using nuclear independent chemical shift (NICS) calculations. ${ }^{34} \mathrm{NICS}_{(0)}$ values of -1.94 and $-3.55 \mathrm{ppm}$ were obtained for the five-membered rings in $\mathbf{1 z w}$ and $\mathbf{1}$, respectively. These relatively small negative $\mathrm{NICS}_{(0)}$ values revealed the non-aromatic nature of the rings. In contrast, the large negative $\operatorname{NICS}_{(0)}$ value of $-\mathbf{1 1 . 3 4} \mathrm{ppm}$ for $\mathbf{1}_{\text {TS-Iv }}$ proved the aromaticity of the transition state, and consequently, the pericyclic nature of the reaction. The lobes in the highest occupied molecular orbital (HOMO) of 1zw indicate that the cyclisation is allowed progress only in disrotatory mode leading to the cis product (1) according to the Woodward-Hoffman rule. ${ }^{35}$ The experimental results are in good agreement with the calculations because for all substrates, the formation of solely the cis product was observed. The stereochemistry of $\mathbf{1}$ (Fig. 5a), 2, and 5 (Fig. S115 and S116, ESI $\dagger$ ) was confirmed by singlecrystal X-ray diffraction. The stereochemistry of 3, 4 and 6-8 was deduced to be cis as the synthetic methods were identical. This deduction was further supported by the high coupling constants (10.9-11.2 Hz) for the imidazoline hydrogens in the NMR spectra.

As a consequence of the electrocyclic nature of the reaction, the diastereoselectivity can be influenced by the method of reaction initiation. Photoirradiation at $254 \mathrm{~nm}$ and $365 \mathrm{~nm}$ for $96 \mathrm{~h}$ resulted in $39 \%$ and $13 \%$ conversion with trans : cis product ratio of 1.42 and 1.61, respectively (Scheme 1).

Furthermore, the thermodynamically favoured trans $\mathbf{9}$ can be selectively obtained by alkali treatment of the cis isomer, similarly to a previously described procedure. ${ }^{13}$ The trans stereochemistry of 9 (Fig. 5b) was indicated by the lower coupling constant of imidazoline hydrogens $(J=8.8 \mathrm{~Hz})$ compared to the case of $1(J=10.9 \mathrm{~Hz})$.

Besides $p$-substituted aldehydes, the synthesis was also performed from $o$-, and $m$-substituted aldehydes, in order to investigate the effect of the substituent position on the reaction (Table 6). Moreover, attempts were made to expand the substrate scope to heterocyclic and non-aromatic aldehydes as well. Comparing the position of substituents (entries 1-2), the $m$-substitution provided the desired product in good yield, but the reaction was slower compared to the $p$-substituted

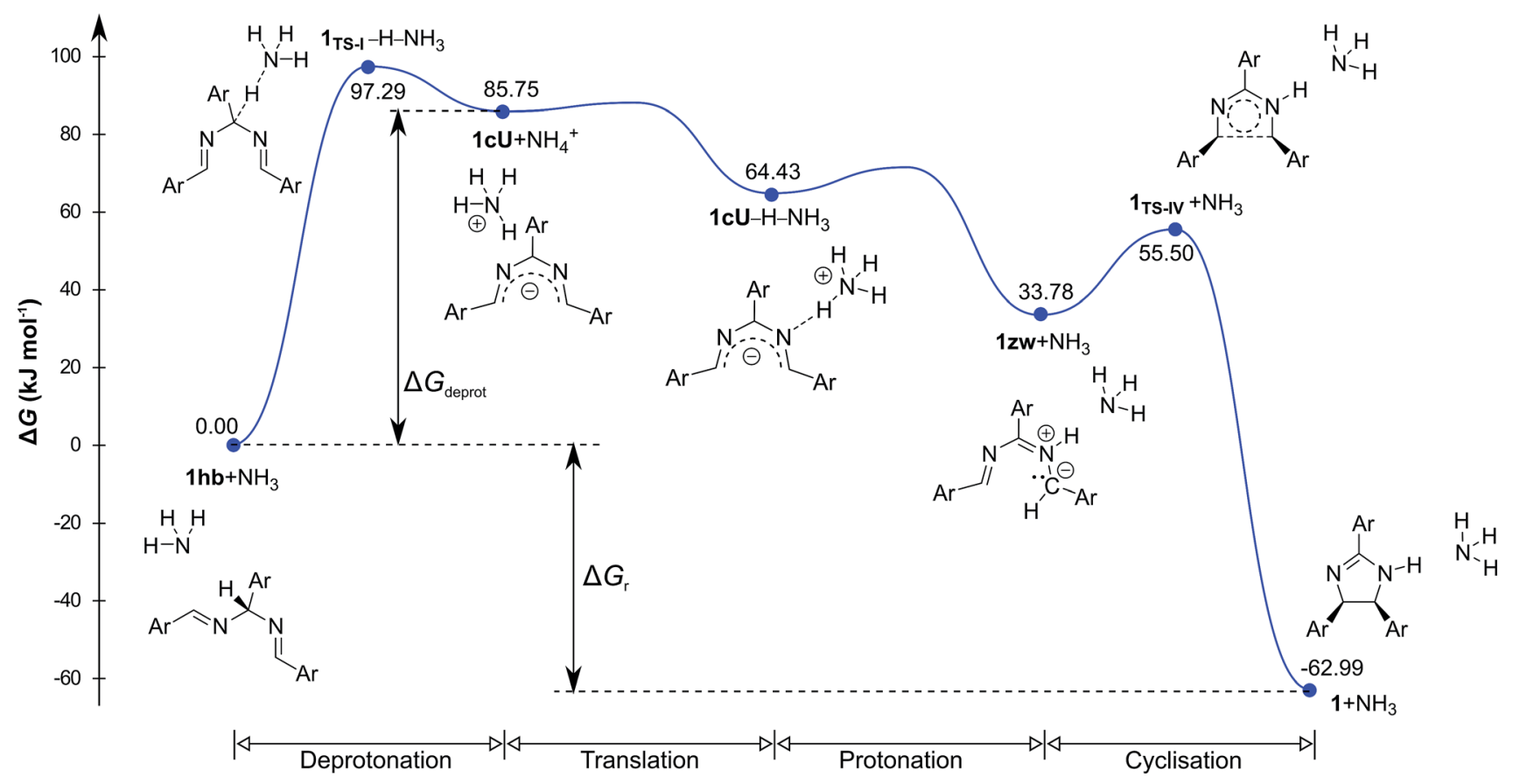

Fig. 4 Computed relative Gibbs free energy profile of hydrobenzamide cyclisation in the presence of ammonia. 
Table 5 Calculated structures and relative DFT (B3LYP/6-31G(d,p)) Gibbs free energies (and enthalpies) of the different conformers of the carbanion intermediate, shaped like $\mathrm{W}, \mathrm{S}$ and $\mathrm{U}(1 \mathrm{cW}, 1 \mathrm{cS}$ and $1 \mathrm{cU})$ originating from the rotation around $\mathrm{N}(6)-\mathrm{C}(3)$ and $\mathrm{C}(3)-\mathrm{N}(7)$ bonds

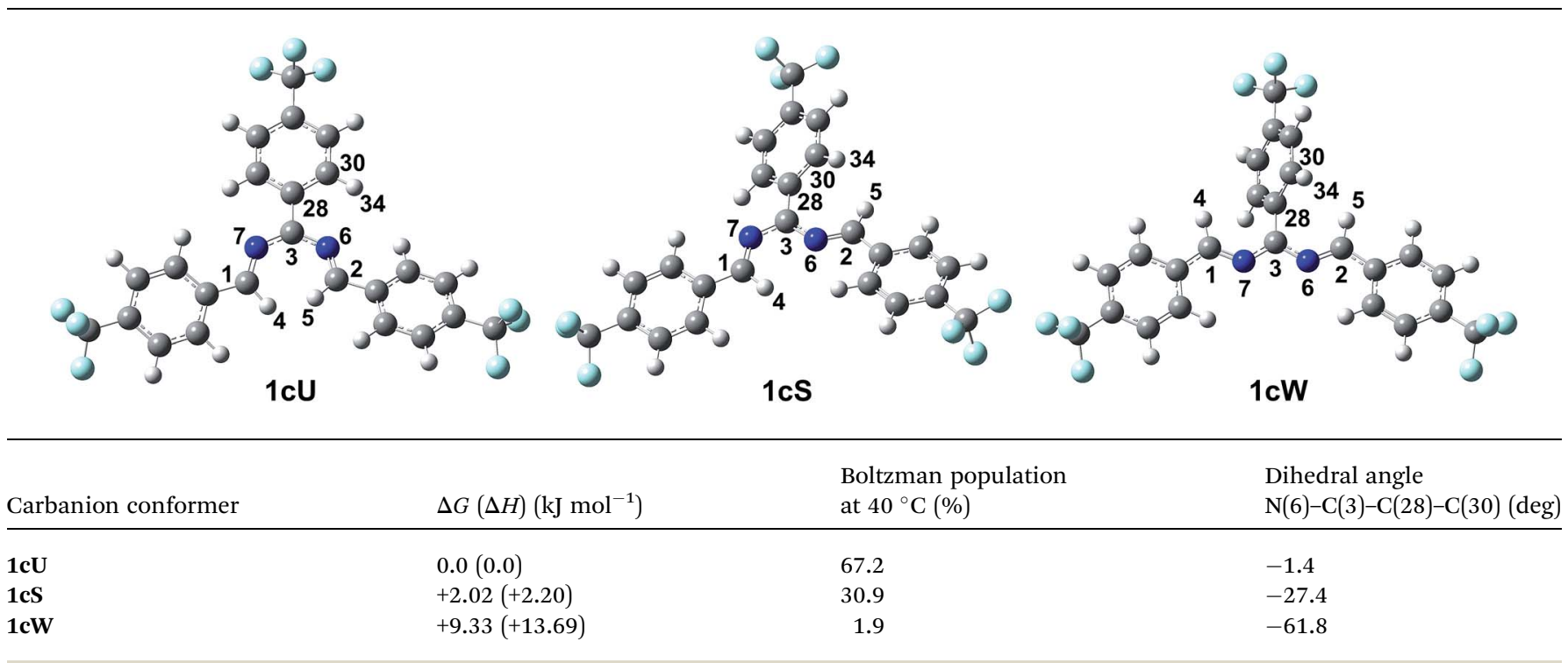

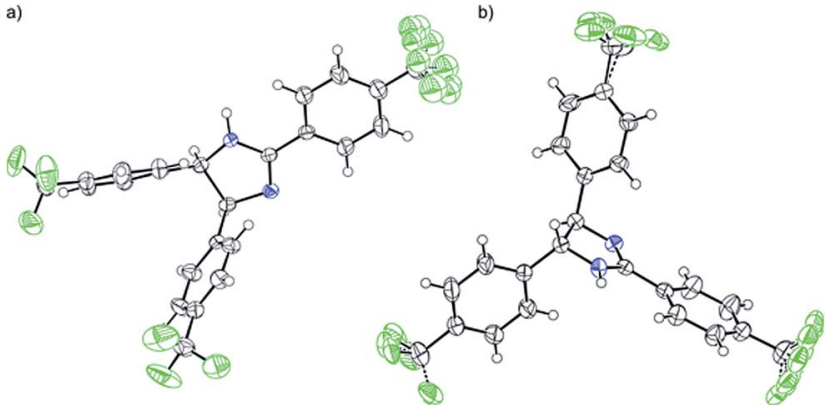

Fig. 5 ORTEP representation of the molecular structure of cis-1 (a) and trans -9 (b) at $50 \%$ probability as determined by single-crystal X-ray diffraction, which revealed that some of the $-\mathrm{CF}_{3}$ groups can have more than one arrangement in the crystal.

analogue. The $o$-substitution did not afford the imidazoline product as a consequence of steric effects, i.e., the close proximity of the bulky $-\mathrm{CF}_{3}$ substituent to the formyl group sterically hinders the reaction. When it was attempted to produce the product from 4-pyridinecarboxaldehyde and $\left(\mathrm{NH}_{4}\right)_{2} \mathrm{CO}_{3}$ with the optimised conditions, a product mixture of imidazoline and imidazole $(1: 1)$ was obtained. However, when $\mathrm{NH}_{4} \mathrm{OAc}$ was used as ammonia source, the desired 2-imidazoline product was isolated in a good yield of $72 \%$. This result suggests that, similarly to $\mathbf{3}$, product $\mathbf{1 1}$ is also sensitive to oxidation under basic conditions. The synthesis of $\mathbf{1 2}$ was performed using trans-cinnamaldehyde and $\left(\mathrm{NH}_{4}\right)_{2} \mathrm{CO}_{3}$ as shown in entry 4 in Table 6. The reaction provided the product in good yield within $24 \mathrm{~h}$, which indicates that highly conjugated aldehydes also afford the desired 2-imidazoline product. Therefore, the reaction was also attempted using ethyl 4-oxobut-2-enoate as a nonaromatic starting material. Similarly to trans-cinnamaldehyde, the consumption of starting material was virtually $100 \%$ within

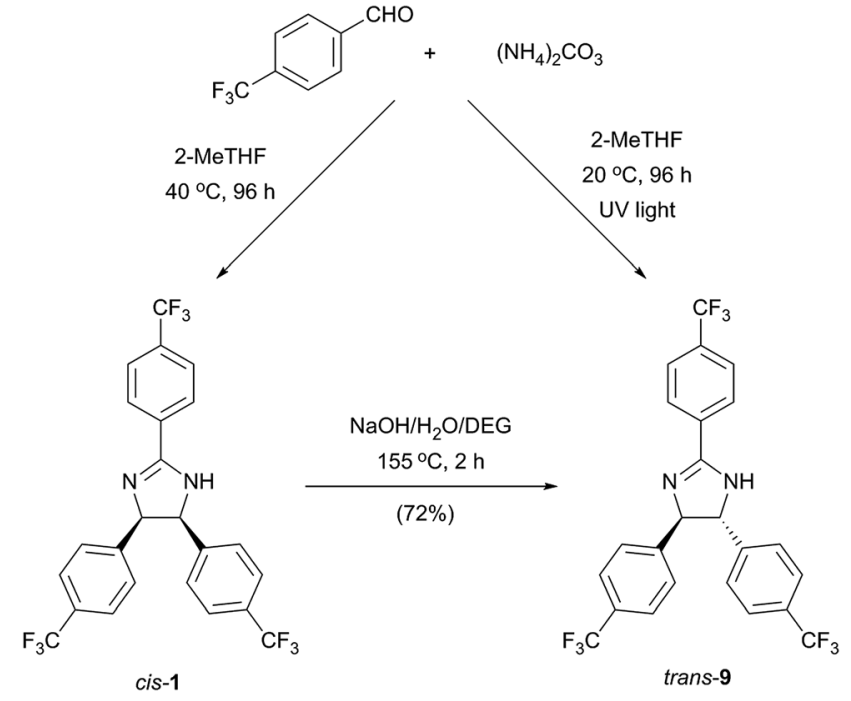

Scheme 1 Synthetic methods yielding cis or trans stereoisomers of a 2-imidazoline.

$24 \mathrm{~h}$ (entry 5). The reaction, however, did not stop at the 2imidazoline product, but through an intramolecular double bond migration a trisubstituted imidazole product was formed instead. Consequently, it could be concluded that a conjugated system which is sterically unhindered is required for the presented synthetic methodology to yield 2-imidazolines.

Most green chemistry articles solely focus on improving the synthetic step without considering the purification and isolation of the product. In order to address the inherent environmental burden of downstream processing, the isolation of the 2imidazoline products was aimed to be performed in a single crystallisation step employing a green solvent, which eliminated the use of tedious chromatography employed in previous 
Table 6 Expanding the substrate scope with 0 - and $m$-substituted, heterocyclic and non-aromatic aldehydes ${ }^{a}$

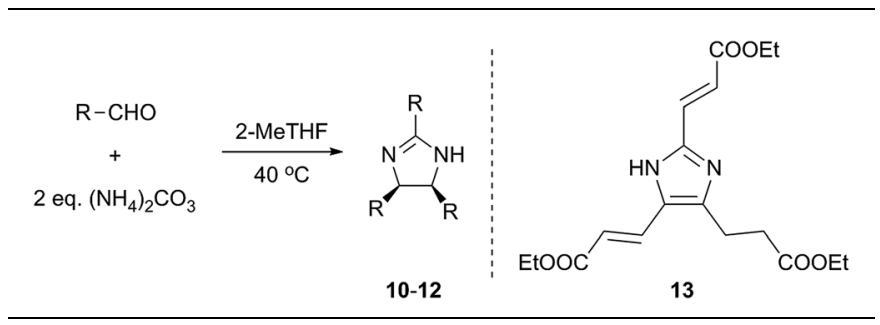

\begin{tabular}{|c|c|c|c|c|}
\hline Entry & $\mathrm{R}-\mathrm{CHO}$ & Time (h) & Yield $^{b}(\%)$ & Product \\
\hline
\end{tabular}

1<smiles>O=Cc1ccccc1C(F)(F)F</smiles>

61

10

2<smiles>O=Cc1cccc(C(F)(F)F)c1</smiles>

36

3<smiles>[O-]Cc1ccncc1</smiles>

72

11

24

84

12<smiles>O=CC=Cc1ccccc1</smiles>

24

$71^{d}$

13 corresponding benzaldehyde substrate impurity (Fig. 6a). Flux is defined as volume of solvent that permeates the membrane per unit area in a given time, while rejection is the ratio of solute concentration in the permeate and the retentate. Permeance is defined as the flux normalised by the applied pressure. The permeances (expressed in $L \mathrm{~m}^{-2} \mathrm{~h}^{-1} \mathrm{bar}^{-1}$ ) obtained for GMTONF-1, GMT-ONF-2, NF030306, and Duramem 300 were $4.39 \pm$ $0.6,5.2 \pm 0.6,0.35 \pm 0.04$, and $0.26 \pm 0.01$, respectively. Despite the relatively low permeance obtained for Duramem 300, it showed excellent product rejection above $99 \%$.

The concentration and purity profiles for single-stage and two-stage diafiltration are shown in Fig. 6b. The detailed description of the mathematical framework can be found in the ESI. $\dagger$ The number of diavolumes is a time-like parameter indicating the progress of the filtration and it is defined as the ratio of permeate and retentate volume. The number of diavolumes required to obtain $99 \%$ product purity with a single-stage and two-stage diafiltration is 5 and 6 , respectively (see dotted lines). In line with expectations, ${ }^{36}$ the two-stage cascade configuration markedly improved the product yield from $95 \%$ to $99.8 \%$. The purification of a post-reaction mixture validated the calculated model. During the process, Duramem 300 at 20 bar demonstrated stable permeance and rejection performance over 8 days of continuous operation in 2-MeTHF (Fig. S118, ESI $\dagger$ ). The solvent consumption of the filtration could be minimised by implementing an additional filtration stage for in situ solvent recovery. ${ }^{28,37}$

\section{Conclusions}

The diastereoselective synthesis of 2,4,5-trisubstituted-2imidazolines was successfully realised from aldehydes and ammonia sources in a one-pot procedure at mild temperature employing green solvents with moderate to high polarity. The effect of the chemical nature of the aldehyde, in particular the position and polarity of aromatic substituents, was systematically investigated. It was found that strongly EWGs with high Hammett sigma constant (e.g. $\left.-\mathrm{NO}_{2},-\mathrm{CF}_{3}\right)$ provide the 2- procedures (see Table 1). Furthermore, the considerable increase in molecular size during the reaction allowed the use of solvent-resistant nanofiltration for product purification. Four membranes, namely GMT-oNF-1, GMT-oNF-2, NF030306, and solvent flux and solute rejection for product $\mathbf{1}$, and the
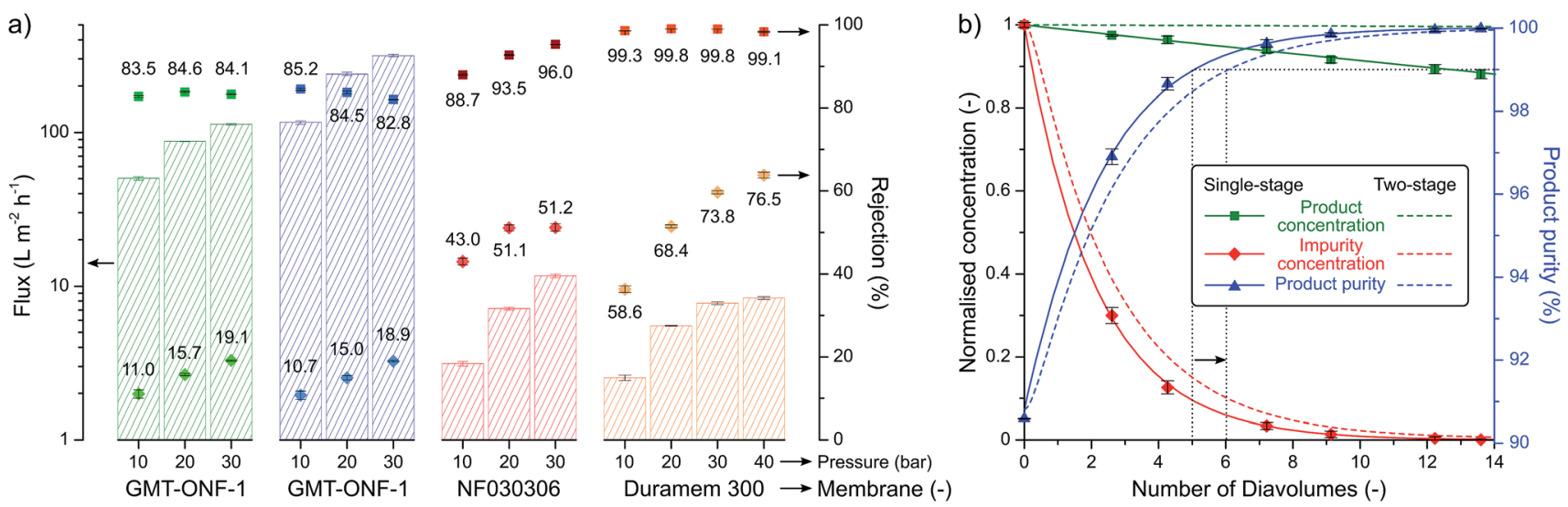

Fig. 6 Separation performance of the solvent-resistant nanofiltration membranes for 2 -imidazoline product purification: $\mathbf{\square}$ and $\boldsymbol{\Delta}$ indicates rejections for 1 , and the corresponding benzaldehyde substrate impurity, respectively (a). Purification performance for single-stage and twostage diafiltration processes. Solid and dashed lines represent the simulated performance based on rejections, while symbols signify experimental points to validate the model used for simulation (b). 
imidazoline product in moderate to good yield. In contrast, weakly EWGs $(-\mathrm{Br})$ and electron-donating groups $(-\mathrm{OH})$ poorly or did not afford the desired product, respectively. Besides the aromatic aldehydes, the synthetic methodology is applicable to sterically unhindered, conjugated analogues. The DFT results refuted two speculations and confirmed that (i) the ionic intermediate gets protonated prior to cyclisation, (ii) the most thermodynamically stable carbanion conformer is U-shaped. DFT modelling, NMR and singlecrystal XRD confirmed that thermal initiation solely yields the cis isomer. It was demonstrated that the diastereoselectivity of the reaction can be changed by photoinitiation, resulting in excess trans isomer, which is a consequence of the electrocyclic nature of the reaction. The feasibility of membrane-based product purification was demonstrated, which provides a green alternative for the conventional chromatographic purification of 2,4,5-trisubstituted-2-imidazolines.

\section{Experimental section}

\section{Materials}

Ammonium acetate ( $>98 \%)$, ammonium bicarbonate $(>99.5 \%)$, ammonium trifluoroacetate (98\%), benzaldehyde (>99\%), 4bromobenzaldehyde (99\%), 4-formylbenzoic acid (97\%), 4hydroxybenzaldehyde (98\%), 4-nitrobenzaldehyde (98\%), 4pyridinecarboxaldehyde (97\%), 3-(trifluoromethyl)benzaldehyde (97\%), 1-butanol (99\%), butyl acetate (>99\%), 1-butyl-3methylimidazolium acetate ([bmim][OAc]; >95\%), cyclopentyl methyl ether (CPME; 99.9\%), dibutyl phthalate (99\%), dimethyl carbonate (99\%), 2-methyltetrahydrofuran (2-MeTHF; contains 250 ppm BHT stabiliser, >99\%), sulfolane (99\%) and 2-phenylbenzimidazole (97\%) were purchased from Sigma-Aldrich. 4Cyanobenzaldehyde (99\%), 4-(dimethylamino)benzaldehyde (95\%), 4-(methylsulfonyl)benzaldehyde (97\%), 4-(pentafluorosulfanyl)benzaldehyde (99\%), 2-(trifluoromethyl)benzaldehyde (98\%), 4-(trifluoromethyl)benzaldehyde (98\%) and ethyl 4-oxobut-2-enoate (95\%) were purchased from Fluorochem. Ammonium carbonate (99\%), thionyl chloride $(99.5 \%)$ and trans-cinnamaldehyde (99\%) were purchased from Acros Organics. Chloroform (HPLC gradient), dimethyl sulfoxide (DMSO; analytical gradient), methanol (MeOH; HPLC gradient) and trifluoroacetic acid (TFA; >99\%) were purchased from Fisher Scientific. Cyrene ${ }^{\mathrm{TM}}$ (dihydrolevoglucosenone; $>99.5 \%$ ) was purchased from Apollo Scientific. Ammonium formate (97\%) was purchased from Alfa Aesar. Methyl tert-butyl ether (MTBE; 99\%) was purchased from Merck. Acetonitrile (HPLC gradient) was purchased from VWR. All reagents and solvents were used as received. The syntheses of methyl 4-formylbenzoate and 4-formyl- $N, N, N$-trimethylanilinium iodide substrates are described in the ESI. $\dagger$

NF010206 membrane was purchased from Solsep BV (Apeldoorn, Netherlands); GMT-oNF-1 and GMT-oNF-2 were purchased from Borsig Membrane Technology GmbH (Gladbeck, Germany); and Duramem 300 was obtained from EvonikMET (Essen, Germany).

\section{Analytical methods}

All reactions were monitored with thin layer chromatography (TLC) using silica gel $60 \mathrm{~F}_{254}$ (Merck) plates; and with high performance liquid chromatography (HPLC). The optimum reaction time, i.e., maximum achievable conversion was determined by HPLC. HPLC analyses were measured on a VWR Hitachi Chromaster instrument with 5160 pump, 5260 autosampler, 5310 column oven, and 5430 diode array detector (DAD). See ESI $\uparrow$ for the HPLC methods. Melting points (values without correction) were measured on a Stuart melting point apparatus SMP3 using $5{ }^{\circ} \mathrm{C} \min ^{-1}$ slope.

The products were characterised by IR, ${ }^{1} \mathrm{H}$ NMR, ${ }^{13} \mathrm{C}$ NMR, ${ }^{19} \mathrm{~F}$ NMR, ${ }^{1} \mathrm{H}$ COSY, ${ }^{1} \mathrm{H}-{ }^{13} \mathrm{C}$ HMBC and ${ }^{1} \mathrm{H}-{ }^{13} \mathrm{C}$ HSQC, mass spectrometry (MS) and, where possible, single-crystal XRD measurements. IR spectra were recorded from dry samples using a Thermo Fisher Nicolet iS5 iD5 ATR-FTIR spectrometer. NMR analyses were performed on a B500 Bruker Avance II+ 500 $\mathrm{MHz}$ instrument. Spectra were processed using the MestReNova software. Low resolution mass spectra were recorded on a Waters SQD2 Single 1 Quadrupole Mass spectrometer used with a Waters Acquity UHPLC using $100 \%$ methanol as mobile phase. Electrospray ionisation technique was used in negative or positive mode. High resolution mass measurements were performed on a Thermo Exactive plus EMR Orbitrap mass spectrometer, used with a Thermo Ultimate 3000 UHPLC using $100 \%$ methanol as mobile phase. Single-crystals were grown by slow evaporation at low-temperature $\left(2{ }^{\circ} \mathrm{C}\right)$ from acetonitrile for X-ray analysis. CCDC 1576088 (1), CCDC 1576089 (2), CCDC 1576090 (5) and CCDC 1582071 (9) contain the supplementary crystallographic data for this paper. $\dagger$

\section{General synthetic procedure}

In a typical procedure, a benzaldehyde substrate $(3 \mathrm{mmol})$ was dissolved in the solvent $(6 \mathrm{~mL})$, followed by the addition of the ammonia source $(6 \mathrm{mmol})$. The reaction mixture was stirred vigorously at the desired temperature. The reaction was followed by TLC $\left(\mathrm{MeOH}-\mathrm{CHCl}_{3} 1: 10 \mathrm{v} / \mathrm{v}\right)$ and HPLC. The reaction was terminated when maximum conversion was reached by filtering the ammonia source. The solvent was evaporated and the crude product was recrystallised.

Cis-2,4,5-tris(4-(trifluoromethyl)phenyl)-4,5-dihydro-1Himidazole (1). ${ }^{1} \mathrm{H}$ NMR $\left(500 \mathrm{MHz}, \mathrm{THF}-d_{8}\right) \delta 8.26(\mathrm{~d}, J=8.1 \mathrm{~Hz}$, $2 \mathrm{H}), 7.83(\mathrm{~d}, J=8.2 \mathrm{~Hz}, 2 \mathrm{H}), 7.43(\mathrm{~s}, 1 \mathrm{H}), 7.33(\mathrm{~d}, J=7.8 \mathrm{~Hz}, 2 \mathrm{H})$, $7.31(\mathrm{~d}, J=7.8 \mathrm{~Hz}, 2 \mathrm{H}), 7.21(\mathrm{~d}, J=8.0 \mathrm{~Hz}, 2 \mathrm{H}), 7.16(\mathrm{~d}, J=$ $8.0 \mathrm{~Hz}, 2 \mathrm{H}), 5.80$ (d, $J=10.9 \mathrm{~Hz}, 1 \mathrm{H}), 5.47$ (d, $J=10.9 \mathrm{~Hz}, 1 \mathrm{H})$; ${ }^{13} \mathrm{C}$ NMR (126 MHz, THF- $\left.d_{8}\right) \delta 164.2,145.4$ (q, $\left.J=1.2 \mathrm{~Hz}\right), 145.2$ $(\mathrm{q}, J=1.2 \mathrm{~Hz}), 135.1(\mathrm{q}, J=1.3 \mathrm{~Hz}), 129.9(\mathrm{q}, J=32 \mathrm{~Hz}), 129.9(\mathrm{q}$, $J=32 \mathrm{~Hz}), 129.4,129.3(\mathrm{q}, J=32 \mathrm{~Hz}), 129.1,128.7,126.2(\mathrm{q}, J=$ $3.5 \mathrm{~Hz}), 125.5(\mathrm{q}, J=3.7 \mathrm{~Hz}), 125.4(\mathrm{q}, J=3.7 \mathrm{~Hz}), 125.3(\mathrm{q}, J=$ $272 \mathrm{~Hz}), 125.2(\mathrm{q}, J=271 \mathrm{~Hz}), 125.0(\mathrm{q}, J=271 \mathrm{~Hz}), 75.9,66.8$; ${ }^{19}$ F NMR (471 MHz, THF- $\left.d_{8}\right) \delta-63.3(\mathrm{~s}, 3 \mathrm{~F}),-63.4(\mathrm{~s}, 3 \mathrm{~F}),-63.5$ (s, 3F); IR (ATR-FTIR) $\nu_{\max } 3101(\mathrm{NH}), 1604(\mathrm{C}=\mathrm{N}), 1473$ (aromatic $\mathrm{C}=\mathrm{C}), 1323(\mathrm{C}-\mathrm{F}), 1159(\mathrm{C}-\mathrm{F}), 1066(\mathrm{C}-\mathrm{F}) \mathrm{cm}^{-1}$; MS (ESI-/SQD2) m/z: $501.2[\mathrm{M}-\mathrm{H}]^{-}$; MS (ESI+/SQD2) m/z: $503.3[\mathrm{M}$ $+\mathrm{H}]^{+}$; HRMS (ESI+/Orbitrap) $m / z$ : calcd for $[\mathrm{M}+\mathrm{H}]^{+} \mathrm{C}_{24} \mathrm{H}_{16} \mathrm{~F}_{9} \mathrm{~N}_{2}$ : 503.1164; found: 503.1154; $D=-2.05 \mathrm{ppm}$; mp: $261-262{ }^{\circ} \mathrm{C}$. 
Yield: 67\% (335 mg) following recrystallisation from MTBE (2 $\mathrm{mL})$. Product 1 was obtained as white crystals.

Cis-2,4,5-tris(4-(trimethylammoniumyl)phenyl)-4,5-dihydro$\mathbf{1 H}$-imidazole iodide (2). Amendments to the general procedure: the aldehyde was dissolved in a mixture of 2-MeTHF $(5 \mathrm{~mL})$ and DMSO $(1 \mathrm{~mL})$. Upon termination of the reaction, the residue was poured onto $50 \mathrm{~mL}$ acetone, followed by the filtration of the precipitate.

${ }^{1} \mathrm{H}$ NMR (500 MHz, DMSO- $\left.d_{6}\right) \delta 8.26(\mathrm{~d}, J=8.8 \mathrm{~Hz}, 2 \mathrm{H}), 8.19$ $(\mathrm{s}, 1 \mathrm{H}) 8.18(\mathrm{~d}, J=9.0 \mathrm{~Hz}, 2 \mathrm{H}), 7.65(\mathrm{~d}, J=9.2 \mathrm{~Hz}, 2 \mathrm{H}), 7.62(\mathrm{~d}, J$ $=9.3 \mathrm{~Hz}, 2 \mathrm{H}), 7.29-6.92(\mathrm{~m}, 4 \mathrm{H}), 5.78(\mathrm{~d}, J=10.9 \mathrm{~Hz}, 1 \mathrm{H}), 5.54$ (d, $J=10.9 \mathrm{~Hz}, 1 \mathrm{H}), 3.69$ (s, 9H), 3.47 (s, 18H); ${ }^{13} \mathrm{C}$ NMR (126 MHz, DMSO- $\left.d_{6}\right) \delta 162.5,148.8,145.8,145.5,141.7,141.7,131.1$, 129.1, 128.9, 128.3, 121.0, 119.4, 119.2, 73.2, 64.0, 56.5, 56.5; IR (ATR-FTIR) $\nu_{\max } 3011(\mathrm{CH}), 1617(\mathrm{C}=\mathrm{N}), 1468(\mathrm{C}(\mathrm{N})-\mathrm{N}), 955$, $938(\mathrm{C}-\mathrm{N}), 845\left(\mathrm{C}-\mathrm{N}^{+} \mathrm{Me}_{3}\right) \mathrm{cm}^{-1}$; HRMS (ESI+/Orbitrap) $\mathrm{m} / \mathrm{z}$ : calcd for $[\mathrm{M}]^{3+} \mathrm{C}_{30} \mathrm{H}_{42} \mathrm{~N}_{5}$ : 157.4473; found: $157.4475 ; D=$ -1.01 ppm; mp: 168.7-169.4 ${ }^{\circ} \mathrm{C}$ decomp. Yield: 83\% (590 mg) following recrystallisation from acetonitrile $(5 \mathrm{~mL})$. Product 2 was obtained as white crystals.

Cis-2,4,5-tris(4-nitrophenyl)-4,5-dihydro-1 $\mathrm{H}$-imidazole ${ }^{1} \mathrm{H}$ NMR $\left(500 \mathrm{MHz}, \mathrm{THF}-d_{8}\right) \delta 8.39(\mathrm{~d}, J=8.4 \mathrm{~Hz}, 2 \mathrm{H}), 8.30(\mathrm{~d}, J=$ $8.4 \mathrm{~Hz}, 2 \mathrm{H}), 8.01-7.85(\mathrm{~m}, 4 \mathrm{H}), 7.62(\mathrm{~s}, 1 \mathrm{H}), 7.32(\mathrm{~d}, J=8.4 \mathrm{~Hz}$, $2 \mathrm{H}), 7.29(\mathrm{~d}, J=8.3 \mathrm{~Hz}, 2 \mathrm{H}), 5.91(\mathrm{~d}, J=11.2 \mathrm{~Hz}, 1 \mathrm{H}), 5.59(\mathrm{~d}, J=$ $11.2 \mathrm{~Hz}, 1 \mathrm{H}) ;{ }^{13} \mathrm{C}$ NMR $\left(126 \mathrm{MHz}, \mathrm{THF}-d_{8}\right) \delta 164.1,150.7,148.3$, 148.2, 148.1, 147.9, 136.9, 130.0, 129.7, 129.3, 124.5, 124.0, 123.6, 76.0, 66.7; IR (ATR-FTIR) $\nu_{\max } 3416(\mathrm{NH}), 3106(\mathrm{CH}), 3081$ $(\mathrm{CH}), 3060(\mathrm{CH}), 1586(\mathrm{C}=\mathrm{N}), 1523\left(\mathrm{NO}_{2}\right), 1448$ (aromatic $\mathrm{C}=$ C), $1344\left(\mathrm{NO}_{2}\right), 860$ (aromatic $\left.\mathrm{CH}\right) \mathrm{cm}^{-1}$; MS (ESI-/SQD2) $\mathrm{m} / \mathrm{z}$ : 432.2 $[\mathrm{M}-\mathrm{H}]^{-}$; MS (ESI+/SQD2) $m / z: 434.2[\mathrm{M}+\mathrm{H}]^{+}$; HRMS (ESI-/Orbitrap) $m / z$ : calcd for $[\mathrm{M}-\mathrm{H}]^{-} \mathrm{C}_{21} \mathrm{H}_{14} \mathrm{~N}_{5} \mathrm{O}_{6}$ : 432.0950; found: $432.0937 ; D=-2.91 \mathrm{ppm}$; mp: $195-200{ }^{\circ} \mathrm{C}$ decomp. Yield: $85 \%$ (367 $\mathrm{mg}$ ) following recrystallisation from 2-MeTHF $(2 \mathrm{~mL})$. Product 3 was obtained as pale yellow crystals.

Cis-2,4,5-tris(4-(methylsulfonyl)phenyl)-4,5-dihydro-1Himidazole (4). ${ }^{1} \mathrm{H}$ NMR (500 MHz, DMSO- $\left.d_{6}\right) \delta 8.31(\mathrm{~d}, J=8.5 \mathrm{~Hz}$, $2 \mathrm{H}), 8.27(\mathrm{~s}, 1 \mathrm{H}), 8.11(\mathrm{~d}, J=8.5 \mathrm{~Hz}, 2 \mathrm{H}), 7.58(\mathrm{~d}, J=8.0 \mathrm{~Hz}, 2 \mathrm{H})$, $7.57(\mathrm{~d}, J=7.7 \mathrm{~Hz}, 2 \mathrm{H}), 7.22(\mathrm{~d}, J=8.6 \mathrm{~Hz}, 2 \mathrm{H}), 7.20(\mathrm{~d}, J=8.6 \mathrm{~Hz}$, $2 \mathrm{H}), 5.85$ (d, $J=11.2 \mathrm{~Hz}, 1 \mathrm{H}), 5.57$ (d, $J=11.3 \mathrm{~Hz}, 1 \mathrm{H}), 3.31$ (s, $3 \mathrm{H}), 3.02(\mathrm{~s}, 3 \mathrm{H}), 3.01(\mathrm{~s}, 3 \mathrm{H}) ;{ }^{13} \mathrm{C}$ NMR (126 MHz, DMSO- $\left.d_{6}\right)$ $\delta$ 163.0, 145.6, 145.5, 142.7, 139.1, 138.7, 134.3, 128.6, 128.4, 127.9, 127.2, 126.2, 126.0, 74.0, 64.6, 43.6, 43.6, 43.4; IR (ATRFTIR) $\nu_{\max } 3162(\mathrm{NH}), 2922(\mathrm{CH}), 1618(\mathrm{C}=\mathrm{N}), 1292(\mathrm{O}=\mathrm{S}=$ O) $\mathrm{cm}^{-1}$; MS (ESI-/SQD2) $\mathrm{m} / \mathrm{z}: 531.3[\mathrm{M}-\mathrm{H}]^{-}$; MS (ESI+/SQD2) $\mathrm{m} /$ $z: 555.3[\mathrm{M}+\mathrm{Na}]^{+}$; HRMS (HESI+/Orbitrap) $m / z$ : calcd for $[\mathrm{M}+\mathrm{Na}]^{+}$ $\mathrm{C}_{24} \mathrm{H}_{24} \mathrm{~N}_{2} \mathrm{O}_{6} \mathrm{~S}_{3} \mathrm{Na}$ : 555.0689; found: 555.0676; $D=-2.29$ ppm; mp: $275-277{ }^{\circ} \mathrm{C}$. Yield: $69 \%$ (369 $\mathrm{mg}$ ) following crystallisation from 2-MeTHF. Product 4 was obtained as white crystals.

Cis-2,4,5-tris(4-(pentafluorosulfanyl)phenyl)-4,5-dihydro- $1 \mathrm{H}$ imidazole (5). ${ }^{1} \mathrm{H}$ NMR $\left(500 \mathrm{MHz}\right.$, THF- $\left.d_{8}\right) \delta 8.24(\mathrm{~d}, J=8.4 \mathrm{~Hz}$, $2 \mathrm{H}), 8.01(\mathrm{~d}, J=8.8 \mathrm{~Hz}, 2 \mathrm{H}), 7.53(\mathrm{~s}, 1 \mathrm{H}), 7.48(\mathrm{~d}, J=8.8 \mathrm{~Hz}, 2 \mathrm{H})$, $7.46(\mathrm{~d}, 2 \mathrm{H}, J=8.8 \mathrm{~Hz}), 7.15(\mathrm{~d}, J=8.8 \mathrm{~Hz}, 3 \mathrm{H}), 7.13(\mathrm{~d}, J=$ $8.7 \mathrm{~Hz}, 3 \mathrm{H}), 5.81$ (d, $J=11.0 \mathrm{~Hz}, 1 \mathrm{H}), 5.48$ (d, $J=11.0 \mathrm{~Hz}, 1 \mathrm{H})$; ${ }^{13} \mathrm{C}$ NMR $\left(126 \mathrm{MHz}\right.$, THF- $\left.d_{8}\right) \delta 163.9,156.2$ (quint, $J=17 \mathrm{~Hz}$ ), 153.4 (quint, $J=17 \mathrm{~Hz}$ ), 153.1 (quint, $J=17 \mathrm{~Hz}$ ), 145.1, 145.0, 134.6, 129.3, 129.1, 128.6, 127.1 (quint, $J=4.6 \mathrm{~Hz}$ ), 126.3 (quint, $J=4.6 \mathrm{~Hz}$ ), 125.9 (quint, $J=4.6 \mathrm{~Hz}$ ), 75.7, 66.4; ${ }^{19} \mathrm{~F} \mathrm{NMR} \mathrm{(471}$
MHz, THF- $\left.d_{8}\right) \delta 84.7-83.0(\mathrm{~m}, 3 \mathrm{~F}), 62.1(\mathrm{~d}, J=149 \mathrm{~Hz}, 4 \mathrm{~F}), 62.0$ (d, $J=149 \mathrm{~Hz}, 4 \mathrm{~F}), 61.9$ (d, $J=149 \mathrm{~Hz}, 4 \mathrm{~F})$; IR (ATR-FTIR) $\nu_{\max }$ $3172(\mathrm{NH}), 1620(\mathrm{C}=\mathrm{N}), 1471$ (aromatic $\mathrm{C}=\mathrm{C}), 816(\mathrm{~S}-\mathrm{F}) \mathrm{cm}^{-1}$; MS (ESI-/SQD2) $m / z: 675.1[\mathrm{M}-\mathrm{H}]^{-}, 711.1[\mathrm{M}+\mathrm{Cl}]^{-}$; MS (ESI+/ SQD2) $m / z: 677.1[\mathrm{M}+\mathrm{H}]^{+}$; HRMS (ESI+/Orbitrap) $m / z$ : calcd for $[\mathrm{M}+\mathrm{H}]^{+} \mathrm{C}_{21} \mathrm{H}_{16} \mathrm{~F}_{15} \mathrm{~N}_{2} \mathrm{~S}_{3}$ : 677.0231; found: 677.0223, $D=$ -1.12 ppm; mp: $264-265{ }^{\circ} \mathrm{C}$. Yield: $87 \%$ (587 $\mathrm{mg}$ ) following recrystallisation from heptane $(2 \mathrm{~mL})$. Product 5 was obtained as white crystals.

Cis-2,4,5-tris(4-cyanophenyl)-4,5-dihydro-1H-imidazole (6). ${ }^{1} \mathrm{H}$ NMR $\left(500 \mathrm{MHz}, \mathrm{THF}-d_{8}\right) \delta 8.20(\mathrm{~d}, J=8.2 \mathrm{~Hz}, 2 \mathrm{H}), 7.88(\mathrm{~d}, J=$ $8.2 \mathrm{~Hz}, 2 \mathrm{H}), 7.47$ (s, 1H), 7.40 (d, $J=8.2 \mathrm{~Hz}, 2 \mathrm{H}), 7.38$ (d, $J=$ $8.2 \mathrm{~Hz}, 2 \mathrm{H}), 7.20$ (d, $J=8.1 \mathrm{~Hz}, 2 \mathrm{H}), 7.16(\mathrm{~d}, J=8.1 \mathrm{~Hz}, 2 \mathrm{H}), 5.79$ $(\mathrm{d}, J=11.1 \mathrm{~Hz}, 1 \mathrm{H}), 5.46$ (d, $J=11.1 \mathrm{~Hz}, 1 \mathrm{H}) ;{ }^{13} \mathrm{C}$ NMR $(126$ MHz, THF- $\left.d_{8}\right) \delta 164.2,145.9,135.1,133.1,132.5,132.1,129.8$, 129.1, 129.0, 119.1, 118.9, 118.8, 115.6, 112.2, 111.6, 76.0, 66.7; IR (ATR-FTIR) $\nu_{\max } 3336(\mathrm{NH}), 3072(\mathrm{CH}), 3051(\mathrm{CH}), 3035(\mathrm{CH})$, $2227(\mathrm{C} \equiv \mathrm{N}), 1604(\mathrm{C}=\mathrm{N}), 1445$ (aromatic $\mathrm{C}=\mathrm{C}), 851$ (aromatic $\mathrm{CH}) \mathrm{cm}^{-1}$; MS (ESI-/SQD2) $\mathrm{m} / \mathrm{z}: 372.3[\mathrm{M}-\mathrm{H}]^{-}$; MS (ESI+/ SQD2) $m / z: 374.3[\mathrm{M}+\mathrm{H}]^{+}, 396.2[\mathrm{M}+\mathrm{Na}]^{+}$; HRMS (ESI+/Orbitrap) $m / z$ : calcd for $[\mathrm{M}+\mathrm{H}]^{+} \mathrm{C}_{24} \mathrm{H}_{16} \mathrm{~N}_{5}$ : 374.1400; found: 374.1395; $D=-1.40 \mathrm{ppm}$; mp: $251-252{ }^{\circ} \mathrm{C}$ (Literature data: ${ }^{\mathbf{1 6}}$ $222-224{ }^{\circ} \mathrm{C}$ ) yield: $68 \%$ (253 $\mathrm{mg}$ ) following recrystallisation from butyl acetate $(3 \mathrm{~mL})$. Product 6 was obtained as white crystals.

Cis-2,4,5-tris(4-(methoxycarbonyl)phenyl)-4,5-dihydro- $1 \mathrm{H}$ imidazole (7). ${ }^{1} \mathrm{H}$ NMR (500 MHz, THF- $\left.d_{8}\right) \delta 8.17$ (d, $J=8.5 \mathrm{~Hz}$, $2 \mathrm{H}$ ), 8.12 (d, $J=8.5 \mathrm{~Hz}, 2 \mathrm{H}), 7.67$ (d, $J=8.3 \mathrm{~Hz}, 4 \mathrm{H}$ ), 7.34 (brs, 1H), 7.22 (br, 2H), 7.12 (br, 2H), 5.75 (brd, $J=9.6 \mathrm{~Hz}, 1 \mathrm{H}), 5.41$ (brd, $J=9.6 \mathrm{~Hz}, 1 \mathrm{H}), 3.91(\mathrm{~s}, 3 \mathrm{H}), 3.75(\mathrm{~s}, 6 \mathrm{H}) ;{ }^{13} \mathrm{C}$ NMR (126 MHz, THF- $\left.d_{8}\right) \delta 166.8,166.6,164.5,146.2,135.6,133.1,130.2$, 129.7, 129.4, 129.0, 128.5, 128.3, 76.1, 67.1, 52.4, 51.9; IR (ATRFTIR) $\nu_{\max } 3315(\mathrm{NH}), 2955(\mathrm{CH}), 1717(\mathrm{C}=\mathrm{O}), 1708(\mathrm{C}=\mathrm{O})$, $1608(\mathrm{C}=\mathrm{N}), 1435$ (aromatic $\mathrm{C}=\mathrm{C}), 1275(\mathrm{C}-\mathrm{C}(\mathrm{O})-\mathrm{O}), 1107(\mathrm{C}-$ $\mathrm{O}-\mathrm{C}) \mathrm{cm}^{-1}$; MS (ESI-/SQD2) $\mathrm{m} / \mathrm{z}: 471.4[\mathrm{M}-\mathrm{H}]^{-}$; MS (ESI+/ SQD2) $m / z: 473.3[\mathrm{M}+\mathrm{H}]^{+}$; HRMS (ESI+/Orbitrap) $m / z$ : calcd for $[\mathrm{M}+\mathrm{H}]^{+} \mathrm{C}_{27} \mathrm{H}_{25} \mathrm{~N}_{2} \mathrm{O}_{6}$ : 473.1707; found: 473.1697; $D=$ -2.14 ppm; mp: $186-188{ }^{\circ} \mathrm{C}$ decomp. Yield: 65\% (310 mg) following recrystallisation from MTBE $(2 \mathrm{~mL})$. Product 7 was obtained as white crystals.

Cis-2,4,5-tris(4-bromophenyl)-4,5-dihydro- $1 \mathrm{H}$-imidazole hydrochloride salt (8). Amendments to the general procedure: upon termination of the reaction, the residue was dissolved in ethyl acetate $(10 \mathrm{~mL})$, and $4 \mathrm{M}$ aqueous $\mathrm{HCl}$ solution $(10 \mathrm{~mL})$ was added, the precipitated product was filtered out.

${ }^{1} \mathrm{H}$ NMR (500 MHz, DMSO- $\left.d_{6}\right) \delta 11.63(\mathrm{~s}, 2 \mathrm{H}), 8.22(\mathrm{~d}, J=$ $8.7 \mathrm{~Hz}, 2 \mathrm{H}), 8.00$ (d, $J=8.7 \mathrm{~Hz}, 2 \mathrm{H}), 7.37$ (d, $J=8.5 \mathrm{~Hz}, 4 \mathrm{H}), 7.09$ $(\mathrm{d}, J=8.5 \mathrm{~Hz}, 4 \mathrm{H}), 5.98(\mathrm{~s}, 2 \mathrm{H}) ;{ }^{13} \mathrm{C}$ NMR (126 MHz, DMSO- $\left.d_{6}\right)$ $\delta$ 165.1, 134.7, 132.9, 131.6, 131.4, 130.4, 129.6, 121.8, 121.7, 64.1; IR (ATR-FTIR) $\nu_{\max } 3315(\mathrm{NH}), 2955(\mathrm{CH}), 1717(\mathrm{C}=\mathrm{O}), 1708(\mathrm{C}=$ $\mathrm{O}), 1608(\mathrm{C}=\mathrm{N}), 1435$ (aromatic $\mathrm{C}=\mathrm{C}), \mathrm{cm}^{-1}$; MS (ESI-/SQD2) $\mathrm{m} /$ $z: 531.1[\mathrm{M}-\mathrm{H}]^{-}$; MS (ESI+/SQD2) $m / z: 473.3[\mathrm{M}+\mathrm{H}]^{+}$; HRMS (ESI-/Orbitrap) $m / z$ : calcd for $[\mathrm{M}+\mathrm{Cl}]^{-} \mathrm{C}_{21} \mathrm{H}_{15} \mathrm{~N}_{2} \mathrm{Br}_{3} \mathrm{Cl}$ : 566.8471; found: $566.8479 ; D=-1.48 \mathrm{ppm}$; mp: $325-326{ }^{\circ} \mathrm{C}$. Yield: $8 \%$ (45 mg). Product 8 was obtained as white crystals.

Trans-2,4,5-tris(4-(trifluoromethyl)phenyl)-4,5-dihydro-1Himidazole (9). 1 (150 $\mathrm{mg}, 0.3 \mathrm{mmol}$ ) was added to the mixture of water $(1 \mathrm{~mL})$, diethylene glycol $(5 \mathrm{~mL})$ and sodium 
hydroxide (19 $\mathrm{mg}, 0.48 \mathrm{mmol}$ ). The reaction mixture was heated to $155{ }^{\circ} \mathrm{C}$ and was maintained at that temperature for $2 \mathrm{~h}$, during which time the sodium salt of $\mathbf{9}$ precipitated. The reaction mixture was cooled down to room temperature, treated with acetic acid glacial $(1 \mathrm{~mL})$, diluted with ethanol $(5 \mathrm{~mL})$, followed by heating to $100{ }^{\circ} \mathrm{C}$ until all remaining solid product dissolved. The mixture was cooled down and basified with $35 \% \mathrm{NH}_{4} \mathrm{OH}(10 \mathrm{~mL})$ to $\mathrm{pH}=9$ upon which white solid precipitated. The precipitation was filtered, washed with ethanol $(5 \mathrm{~mL})$.

${ }^{1} \mathrm{H}$ NMR $\left(500 \mathrm{MHz}, \mathrm{THF}-d_{8}\right) \delta 8.22(\mathrm{~d}, J=8.1 \mathrm{~Hz}, 2 \mathrm{H}), 7.81(\mathrm{~d}$, $J=8.3 \mathrm{~Hz}, 2 \mathrm{H}), 7.70(\mathrm{~d}, J=8.2 \mathrm{~Hz}, 2 \mathrm{H}), 7.65(\mathrm{~d}, J=8.2 \mathrm{~Hz}, 2 \mathrm{H})$, 7.58 (d, $J=8.1 \mathrm{~Hz}, 2 \mathrm{H}), 7.48$ (brs, $1 \mathrm{H}), 7.47$ (d, $J=8.3 \mathrm{~Hz}, 2 \mathrm{H})$, $5.14(\mathrm{~d}, J=8.8 \mathrm{~Hz}, 1 \mathrm{H}), 4.81(\mathrm{dd}, J=8.8$ and $2.3 \mathrm{~Hz}, 1 \mathrm{H}) ;{ }^{13} \mathrm{C}$ NMR (126 MHz, THF- $\left.d_{8}\right) \delta 163.2,149.4(\mathrm{q}, J=1.3 \mathrm{~Hz}), 149.2(\mathrm{q}, J$ $=1.3 \mathrm{~Hz}), 135.1(\mathrm{q}, J=1.3 \mathrm{~Hz}), 133.0(\mathrm{q}, J=32 \mathrm{~Hz}), 130.6(\mathrm{q}, J=$ $32 \mathrm{~Hz}), 130.1$ (q, $J=32 \mathrm{~Hz}), 129.1,128.4,128.1,126.6$ (q, $J=3.9$ $\mathrm{Hz}), 126.2$ (q, $J=3.9 \mathrm{~Hz}), 126.2(\mathrm{q}, J=3.9 \mathrm{~Hz}), 125.6(\mathrm{q}, J=272$ $\mathrm{Hz}), 125.4(\mathrm{q}, J=272 \mathrm{~Hz}), 125.2(\mathrm{q}, J=272 \mathrm{~Hz}), 81.0,71.0 ;{ }^{19} \mathrm{~F}$ NMR $\left(471 \mathrm{MHz}, \mathrm{THF}-d_{8}\right) \delta-63.1(\mathrm{~s}, 3 \mathrm{~F}),-63.2(\mathrm{~s}, 3 \mathrm{~F}),-63.6(\mathrm{~s}$, 3F); IR (ATR-FTIR) $\nu_{\max } 3082(\mathrm{NH}), 1601(\mathrm{C}=\mathrm{N}), 1485$ (aromatic $\mathrm{C}=\mathrm{C}), 1324(\mathrm{C}-\mathrm{F}), 1162(\mathrm{C}-\mathrm{F}), 1067(\mathrm{C}-\mathrm{F}) \mathrm{cm}^{-1}$; MS (ESI-/SQD2) $m / z: 501.2[\mathrm{M}-\mathrm{H}]^{-}$; MS (ESI+/SQD2) $m / z: 503.2[\mathrm{M}+\mathrm{H}]^{+}$; HRMS (ASAP+/Orbitrap) $m / z$ : calcd for $[\mathrm{M}+\mathrm{H}]^{+} \mathrm{C}_{24} \mathrm{H}_{16} \mathrm{~F}_{9} \mathrm{~N}_{2}$ : 503.1164; found: $503.1148 ; D=-3.24 \mathrm{ppm}$; mp: $283-284{ }^{\circ} \mathrm{C}$. Yield: $72 \%$ (108 $\mathrm{mg}$ ) following recrystallisation from toluene $(5 \mathrm{~mL})$. Product 9 was obtained as white crystals.

Cis-2,4,5-tris(3-(trifluoromethyl)phenyl)-4,5-dihydro-1H-imidazole (10). Amendments to the general procedure: upon completion of the reaction, the residue was treated with $25 \mathrm{~mL}$ $1 \mathrm{M} \mathrm{HCl}$ solution in order to dissociate the hydrobenzamide intermediate. The product and starting material was extracted with ethyl acetate $(20 \mathrm{~mL})$, followed by $35 \%$ aq. $\mathrm{NH}_{3}(20 \mathrm{~mL})$ wash at $\mathrm{pH}=9$. The organic phase was washed with water $(20 \mathrm{~mL})$, and brine $(20 \mathrm{~mL})$. Ethyl acetate and the starting material were evaporated at $83{ }^{\circ} \mathrm{C}, 40$ mbar.

${ }^{1} \mathrm{H}$ NMR $\left(500 \mathrm{MHz}, \mathrm{THF}-d_{8}\right) \delta 8.39(\mathrm{~s}, 1 \mathrm{H}), 8.38(\mathrm{~d}, J=7.7 \mathrm{~Hz}$, $1 \mathrm{H}), 7.86(\mathrm{~d}, J=7.8 \mathrm{~Hz}, 1 \mathrm{H}), 7.72(\mathrm{t}, J=8.0 \mathrm{~Hz}, 1 \mathrm{H}), 7.54$ (brs, 1H), 7.32-7.22 (m, 6H), 7.22-7.14 (m, 2H), $5.80(\mathrm{br}, 1 \mathrm{H}), 5.52(\mathrm{br}$, $1 \mathrm{H}) ;{ }^{13} \mathrm{C}$ NMR $\left(126 \mathrm{MHz}, \mathrm{THF}-d_{8}\right) \delta 164.2,142.2,132.4,132.3$ (br), $132.2(\mathrm{q}, J=1.0 \mathrm{~Hz}), 131.6(\mathrm{br}), 131.5(\mathrm{q}, J=32 \mathrm{~Hz}), 130.3$, 129.3 (br), 129.0 (br), 128.2 (q, $J=3.8 \mathrm{~Hz}$ ), 125.6 (br), 125.3 (q, $J$ $=272 \mathrm{~Hz}), 125.1$ (q, $J=4.0 \mathrm{~Hz}), 124.9$ (br), 124.5 (br), 123.9 (br), 75.7, 66.6; ${ }^{19} \mathrm{~F}$ NMR $\left(471 \mathrm{MHz}, \mathrm{THF}-d_{8}\right) \delta-63.4(\mathrm{~s}, 3 \mathrm{~F}),-63.6(\mathrm{~s}$, $3 \mathrm{~F}),-63.7$ (s, 3F); IR (ATR-FTIR) $\nu_{\max } 3137(\mathrm{NH}), 1615(\mathrm{C}=\mathrm{N})$, 1114 (aromatic $\mathrm{C}=\mathrm{C}$ ), 1326 (C-F), 1160 (C-F), $\mathrm{cm}^{-1}$; HRMS (ESI+/Orbitrap) $m / z$ : calcd for $[\mathrm{M}+\mathrm{H}]^{+} \mathrm{C}_{24} \mathrm{H}_{16} \mathrm{~F}_{9} \mathrm{~N}_{2}$ : 503.1164; found: $503.1161 ; D=-0.65 \mathrm{ppm}$. Yield: $61 \%$ (306 mg). Product 10 was obtained as pale yellow resin.

Cis-2,4,5-tri(4-pyridyl)-4,5-dihydro- $1 \mathrm{H}$-imidazole Amendments to the general procedure: upon completion of the reaction, the solvent was evaporated and the crude product was dissolved in ethyl acetate $(20 \mathrm{~mL})$ and sat. aq. $\mathrm{NaHCO}_{3}(20 \mathrm{~mL})$ at $\mathrm{pH}=9$. The two phases were separated. The aqueous phase was collected, sat. brine solution $(30 \mathrm{~mL})$ was added and it was extracted with ethyl acetate $(50 \mathrm{~mL})$ three times. The combined organic phases were dried over $\mathrm{MgSO}_{4}$, filtered and the solvent was evaporated.

${ }^{1} \mathrm{H}$ NMR (500 MHz, $\left.\mathrm{CD}_{3} \mathrm{OD}\right) \delta 8.78(\mathrm{~d}, J=6.1 \mathrm{~Hz}, 2 \mathrm{H}), 8.24(\mathrm{~d}$, $J=6.1 \mathrm{~Hz}, 4 \mathrm{H}), 7.99(\mathrm{~d}, J=6.2 \mathrm{~Hz}, 2 \mathrm{H}), 7.14(\mathrm{~d}, J=6.0 \mathrm{~Hz}, 4 \mathrm{H})$, 5.80 (br, 1H), 5.64 (br, 1H); ${ }^{13} \mathrm{C}$ NMR (126 MHz, $\left.\mathrm{CD}_{3} \mathrm{OD}\right) \delta 166.2$, 151.1, 150.1, 149.7, 138.7, 124.8, 124.2, 123.3, 74.5, 65.7; IR (ATR-FTIR) $\nu_{\max } 3156(\mathrm{NH}), 3033(\mathrm{CH}), 1596$ (aromatic $\mathrm{C}=\mathrm{N}$ ), 1473 (aromatic $\mathrm{C}=\mathrm{C}$ ) $\mathrm{cm}^{-1}$; HRMS (ESI-/Orbitrap) $\mathrm{m} / \mathrm{z}$ : $300.1248[\mathrm{M}-\mathrm{H}]^{-}$; HRMS (ESI+/Orbitrap) $m / z$ : calcd for $[\mathrm{M}+$ $\mathrm{Na}]^{+} \mathrm{C}_{18} \mathrm{H}_{15} \mathrm{~N}_{5} \mathrm{Na}$ : 324.1220; found: 324.1210; $D=-2.29 \mathrm{ppm}$; mp: 94.0-95.2 ${ }^{\circ} \mathrm{C}$ decomp. Yield: $72 \%$ (218 mg). Product 11 was obtained as white crystals.

Cis-2,4,5-tri((E)-styryl)-4,5-dihydro-1H-imidazole $\quad(12) . \quad{ }^{1} \mathrm{H}$ NMR $\left(500 \mathrm{MHz}, \mathrm{THF}-d_{8}\right) \delta 7.54(\mathrm{~d}, J=7.2 \mathrm{~Hz}, 2 \mathrm{H}), 7.37-7.33(\mathrm{~m}$, $2 \mathrm{H}), 7.34(\mathrm{~d}, J=7.5 \mathrm{~Hz}, 4 \mathrm{H}), 7.28(\mathrm{~d}, J=7.3 \mathrm{~Hz}, 1 \mathrm{H}), 7.25$ (d, $J=$ $16.7 \mathrm{~Hz}, 1 \mathrm{H}), 7.21(\mathrm{t}, J=7.6 \mathrm{~Hz}, 4 \mathrm{H}), 7.13(\mathrm{t}, J=7.3 \mathrm{~Hz}, 2 \mathrm{H}), 6.81$ $(\mathrm{d}, J=16.7 \mathrm{~Hz}, 1 \mathrm{H}), 6.62$ (brd, 2H), 6.70-6.00 (brs, 1H), 6.28 (d, $J$ $=15.8,1 \mathrm{H}), 6.27(\mathrm{~d}, J=15.8,1 \mathrm{H}), 4.68(\mathrm{br}, 2 \mathrm{H}) ;{ }^{13} \mathrm{C}$ NMR $(126$ MHz, THF- $\left.d_{8}\right) \delta 163.6,138.5,137.3,137.0,131.7,129.8,129.6$, 129.2, 128.0, 127.2, 120.4; IR (ATR-FTIR) $\nu_{\max } 3026(\mathrm{CH}), 1647$ (non-aromatic $\mathrm{C}=\mathrm{C}), 1577(\mathrm{C}=\mathrm{N}), 966$ (aromatic $\mathrm{C}-\mathrm{H}) \mathrm{cm}^{-1}$; MS (ESI-/SQD2) $m / z: 375.3[\mathrm{M}-\mathrm{H}]^{-}$; MS (ESI+/SQD2) $m / z: 377.7$ $[\mathrm{M}+\mathrm{H}]^{+}$; HRMS (ESI+/Orbitrap) $m / z$ : calcd for $[\mathrm{M}+\mathrm{H}]^{-}$ $\mathrm{C}_{27} \mathrm{H}_{25} \mathrm{~N}_{2}$ : 377.2012; found: $377.2009 ; D=-0.86$ ppm; mp: $108-$ $109{ }^{\circ} \mathrm{C}$. Yield: $84 \%$ (317 $\mathrm{mg}$ ) following recrystallisation from MTBE (3 mL). Product 12 was obtained as pale yellow crystals.

2,4(5)-Bis((1E)-3-ethoxy-3-oxoprop-1-enyl)-5(4)-((1E)-3ethoxy-3-oxopropyl)imidazole hydrochloride salt (13). Amendments to the general procedure: upon completion of the reaction, the crude product was purified by preparative HPLC (see $\left.\mathrm{ESI}^{\dagger}\right)$. The combined fractions were treated with $4 \mathrm{M}$ aq. $\mathrm{HCl}$, followed by the evaporation of methanol under vacuum, and the removal of water via lyophilisation. Compound $\mathbf{1 3}$ is heat sensitive and its free base form is unstable.

${ }^{1} \mathrm{H}$ NMR (500 MHz, DMSO- $\left.d_{6}\right) \delta 7.54(\mathrm{~d}, J=15.9 \mathrm{~Hz}, 1 \mathrm{H}), 7.40$ $(\mathrm{d}, J=16.2 \mathrm{~Hz}, 1 \mathrm{H}), 7.16(\mathrm{~d}, J=16.2 \mathrm{~Hz}, 1 \mathrm{H}), 6.75(\mathrm{~d}, J=15.9 \mathrm{~Hz}$, $1 \mathrm{H}), 4.23$ (q, $J=7.1 \mathrm{~Hz}, 2 \mathrm{H}), 4.20$ (q, $J=7.1 \mathrm{~Hz}, 2 \mathrm{H}), 4.03$ (q, $J=$ $7.1 \mathrm{~Hz}, 2 \mathrm{H}), 3.03(\mathrm{t}, J=7.2 \mathrm{~Hz}, 2 \mathrm{H}), 2.75(\mathrm{t}, J=7.2 \mathrm{~Hz}, 2 \mathrm{H}), 1.27(\mathrm{t}$, $J=7.1 \mathrm{~Hz}, 3 \mathrm{H}), 1.26(\mathrm{t}, J=7.1 \mathrm{~Hz}, 3 \mathrm{H}), 1.15(\mathrm{t}, J=7.1 \mathrm{~Hz}, 3 \mathrm{H}) ;{ }^{13} \mathrm{C}$ NMR (126 MHz, DMSO- $\left.d_{6}\right) \delta 171.4,165.8,164.9,141.8,138.5$, 129.4, 127.9, 126.6, 125.1, 118.3, 60.9, 60.3, 60.2, 32.7, 19.6, 14.2, 14.1, 14.0. IR (ATR-FTIR) $\nu_{\max } 1718(\mathrm{C}=\mathrm{O}), 1707(\mathrm{C}=\mathrm{O}), 1655$ (imidazolium $\mathrm{C}=\mathrm{C}$ ), $1185(\mathrm{C}-\mathrm{C}(\mathrm{O})-\mathrm{O}) \mathrm{cm}^{-1}$; MS (ESI-/SQD2) $\mathrm{m} / \mathrm{z}$ : $363.3[\mathrm{M}-\mathrm{H}]^{-}$; MS (ESI+/SQD2) $m / z: 387.4[\mathrm{M}+\mathrm{Na}]^{+}$; HRMS (ESI+/Orbitrap) $m / z$ : calcd for $[\mathrm{M}+\mathrm{Na}]^{-} \mathrm{C}_{18} \mathrm{H}_{24} \mathrm{~N}_{2} \mathrm{O}_{6} \mathrm{Na}$ : 387.1527; found: $387.1515 ; D=-2.99 \mathrm{ppm}$; mp: 96.3-97.1 ${ }^{\circ} \mathrm{C}$ decomp. Yield: $71 \%$ (285 mg). Product 13 was obtained as white crystals.

\section{Reaction kinetics}

The $p$-substituted aldehyde ( $3 \mathrm{mmol}$ ) was dissolved in 2-MeTHF (6 $\mathrm{mL}$ ), followed by the addition of an internal standard (2phenylbenzimidazole, $78 \mathrm{mg}, \quad 0.4 \mathrm{mmol}$ for 4-nitrobenzaldehyde, methyl 4-formylbenzoate; and dibutyl phthalate, $278 \mathrm{mg}, 1 \mathrm{mmol}$ for 4-(trifluoromethyl) benzaldehyde and 4(pentafluorosulfanyl)benzaldehyde). A sample of $10 \mu \mathrm{L}$ was collected $(t=0)$, followed by the addition of $\left(\mathrm{NH}_{4}\right)_{2} \mathrm{CO}_{3}(577 \mathrm{mg}$, 


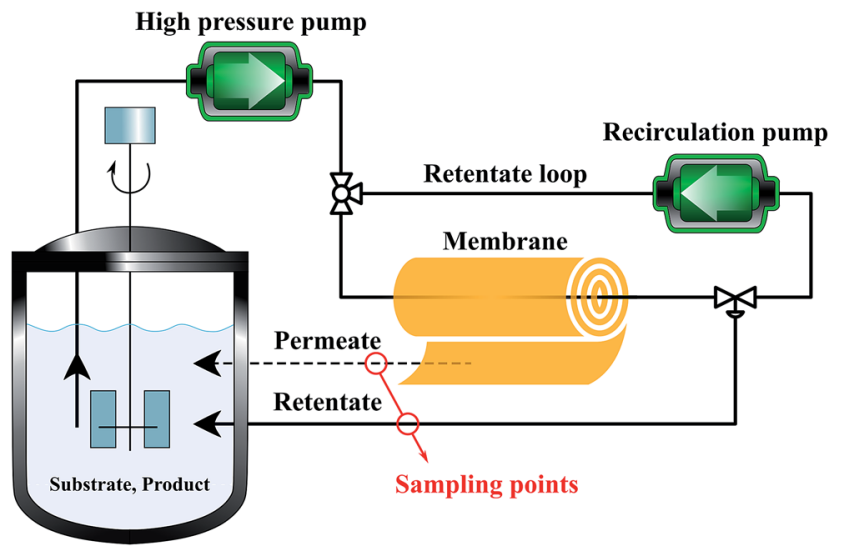

Fig. 7 Schematic process configuration for membrane screening, i.e. determination of solute rejection and flux at 10-40 bar pressure using different membranes.

$6 \mathrm{mmol}$ ) to initiate the reaction. Further samples were periodically collected, and diluted with a mixture of acetic acid, water and DMF $(1: 1: 8 \mathrm{v} / \mathrm{v})$. Samples were analysed by HPLC. The mathematical framework can be found in the ESI. $\dagger$

\section{Membrane separation}

Membranes with an area of $52.8 \mathrm{~cm}^{2}$ were screened using a mixture of 4-(trifluoromethyl)benzaldehyde and product $\mathbf{1}$, at $0.5 \mathrm{~g} \mathrm{~L}^{-1}$ concentration each. The membrane screening was performed in a typical nanofiltration rig operated in cross-flow configuration (Fig. 7). A recirculation pump set at $1 \mathrm{~L} \mathrm{~min}^{-1}$ ensured homogeneous solute concentration in the retentate loop. The membranes were conditioned at each pressure for 24 hours prior to measurements to ensure steady-state operation. The solvent flux was obtained by measuring the volume of permeate passing through the membrane $\left(V_{\mathrm{p}}\right)$ in a definite time $(t)$ and membrane area $(A)$ as shown in eqn (4), while the solute rejection of solute was calculated from the ratio of solute concentration in the permeate $\left(C_{\mathrm{P}}\right)$ and the solute concentration in the retentate $\left(C_{\mathrm{R}}\right)$ as defined in eqn (5). The filtration of postreaction mixture was performed at 20 bar using Duramem 300 membrane with an area of $52.8 \mathrm{~cm}^{2}$. Fresh solvent was continuously added to compensate the permeate volume, keeping the system volume constant at $60 \mathrm{~mL} .100 \mu \mathrm{L}$ samples of permeate and retentate were periodically taken for analysis.

$$
\begin{gathered}
\text { Flux }=\frac{V_{\mathrm{p}}}{A t} \\
\text { Rejection }=\left(1-\frac{C_{\mathrm{p}}}{C_{\mathrm{R}}}\right) \times 100 \%
\end{gathered}
$$

\section{Conflicts of interest}

There are no conflicts to declare.

\section{Acknowledgements}

The authors would like to express their gratitude to Mr Gareth David Smith and the MS laboratory (The University of Manchester) for MS measurements, to Dr Jozsef Kupai (Budapest University of Technology and Economics) for melting point measurements, to Dr Zoltan Mucsi (Femtonics Ltd., Budapest) for his guidance with DFT calculations, and Dr Peter Pogany (GlaxoSmithKline Ltd) and Prof. Krishna Persaud (The University of Manchester) for their valuable comments during the preparation of the manuscript. This work was supported by the Engineering and Physical Sciences Research Council [BioProNET BIV Nov15 Szekely]; the Biotechnology and Biological Sciences Research Council [BioProNET BIV Nov15 Szekely, BB/ L013770/1].

\section{Notes and references}

1 X. Guinchard, Y. Vallee and J. N. Denis, J. Org. Chem., 2007, 72, 3972-3975.

2 M. Krasavin, Eur. J. Med. Chem., 2015, 97, 525-537.

3 R. Tyagi, V. K. Tyagi and S. K. Pandey, J. Oleo Sci., 2007, 56, 211-222.

4 K. Zhuo, Q. Du, G. Bai, C. Wang, Y. Chen and J. Wang, Carbohydr. Polym., 2015, 115, 49-53.

5 J. Li, D. Jia, Z. Guo, Y. Liu, Y. Lyu, Y. Zhoua and J. Wanga, Green Chem., 2017, 19, 2675-2686.

6 H. Liu and D. M. Du, Adv. Synth. Catal., 2009, 351, 489-519.

7 H. Liu and D. M. Du, Adv. Synth. Catal., 2010, 352, 11131118.

8 X. Du, H. Liu and D. M. Du, Eur. J. Org. Chem., 2011, 2011, 786-793.

9 X. B. Bu, Y. Yu, B. Li, L. Zhang, J. J. Chen and Y. L. Zhao, Adv. Synth. Catal., 2017, 359, 351-356.

10 A. Wang, M. Bernasconi and A. Pfaltz, Adv. Synth. Catal., 2017, 359, 2523-2529.

11 E. J. Corey and F. N. M. Kuhnle, Tetrahedron Lett., 1997, 38, 8631-8634.

12 O. F. Williams and J. C. Bailar, J. Am. Chem. Soc., 1959, 81, 4464-4469.

13 D. C. Braddock, J. M. Redmond, S. A. Hermitage and A. J. P. White, Adv. Synth. Catal., 2006, 348, 911-916.

$14 \mathrm{~J}$. Tsuji, K. Sakai, H. Nemoto and H. Nagashima, J. Mol. Catal., 1983, 18, 169-176.

15 R. Oi and K. B. Sharpless, Tetrahedron Lett., 1991, 32, 9991002.

16 D. H. Hunter and S. K. Sim, Can. J. Chem., 1972, 50, 669-677.

17 M. L. Larter, M. Phillips, F. Ortega, G. Aguirre, R. Somanathan and P. J. Walsh, Tetrahedron Lett., 1998, 39, 4785-4788.

18 B. Lecea, A. Arrieta and F. P. Cossio, J. Org. Chem., 2005, 70, 1035-1041.

19 H. Uchida, T. Shimizu, P. Y. Reddy, S. Nakamura and T. Toru, Synthesis, 2003, 8, 1236-1240.

20 F. Wang, Q. Liao and C. Xi, Synth. Commun., 2012, 42, 905913. 
21 P. Anastas and N. Eghbali, Chem. Soc. Rev., 2010, 39, 301312.

22 R. K. Henderson, C. Jimenez-Gonzalez, D. J. C. Constable, S. R. Alston, G. G. A. Inglis, G. Fisher, J. Sherwood, S. T. Binks and A. D. Curzons, Green Chem., 2011, 13, 854862.

23 C. Jimenez-Gonzalez, A. D. Curzons, D. J. C. Constable and V. L. Cunningham, Clean Technol. Environ. Policy, 2005, 7, 42-50.

24 D. Prat, A. Wells, J. Hayler, H. Sneddon, C. R. McElroy, S. Abou-Shehada and P. J. Dunn, Green Chem., 2016, 18, 288-296.

25 C. M. Alder, J. D. Hayler, R. K. Henderson, A. M. Redman, L. Shukla, L. E. Shuster and H. F. Sneddon, Green Chem., 2016, 18, 3879-3890.

26 G. Szekely, M. F. Jimenez-Solomon, P. Marchetti, J. F. Kim and A. G. Livingston, Green Chem., 2014, 16, 4440-4473.

27 G. Szekely, M. Gil, B. Sellergen, W. Heggie and F. C. Ferreira, Green Chem., 2013, 15, 210-225.

28 T. Fodi, C. Didaskalou, J. Kupai, G. T. Balogh, P. Huszthy and G. Szekely, ChemSusChem, 2017, 10, 3435-3444.

29 J. Sherwood, M. De Bruyn, A. Constantinou, L. Moity, C. R. McElroy, T. J. Farmer, T. Duncan, W. Raverty,
A. J. Hunt and J. H. Clark, Chem. Commun., 2014, 50, 96509652.

30 K. L. Wilson, A. R. Kennedy, J. Murray, B. Greatex, C. Jamieson and A. J. B. Watson, Beilstein J. Org. Chem., 2016, 12, 2005-2011.

31 M. B. Smith and J. March, in March's Advanced Organic Chemistry: Reactions, Mechanism and Structure, John Wiley \& Sons Ltd, Hoboken, New Jersey, 6th edn, 2007, ch. 8, pp. 356-394.

32 J. H. Xu, Q. Jiang and C. C. Guo, J. Org. Chem., 2013, 78, 11881-11886.

33 C. Hansch, A. Leo and R. W. Taft, Chem. Rev., 1991, 91, 165195.

34 Z. Chen, C. S. Wannere, C. Corminboeuf, R. Puchta and P. von Rague Schleyer, Chem. Rev., 2005, 105, 3842-3888.

35 R. B. Woodward and R. J. Hoffmann, J. Am. Chem. Soc., 1965, 87, 395-397.

36 J. F. Kim, G. Szekely, I. B. Valtcheva and A. G. Livingston, Green Chem., 2014, 16, 133-145.

37 M. Schaepertoens, C. Didaskalou, J. F. Kim, A. G. Livingston and G. Szekely, J. Membr. Sci., 2016, 514, 646-658. 